\title{
Evaluation of Parametric Limitations in Simulating Greenhouse Gas Fluxes from Irish Arable Soils Using Three Process-Based Models
}

\author{
Mohammad I. Khalil1*, Mohamed Abdalla², Gary Lanigan³, Bruce Osborne ${ }^{1}$, \\ Christoph Müller ${ }^{1,4}$ \\ ${ }^{1}$ UCD School of Biology \& Environmental Science and UCD Earth Institute, University College Dublin, Dublin, \\ Ireland \\ ${ }^{2}$ Institute of Biological \& Environmental Sciences, University of Aberdeen, Scotland, UK \\ ${ }^{3}$ Teagasc Environment Research Centre, Johnstown Castle, Wexford, Ireland \\ ${ }^{4}$ Department of Plant Ecology, Justus-Liebig-University Giessen, Giessen, Germany \\ Email: "Ibrahim.khalil@ucd.ie, "mi.khalil.dr@gmail.com
}

Received 8 June 2016; accepted 13 August 2016; published 16 August 2016

Copyright (C) 2016 by authors and Scientific Research Publishing Inc.

This work is licensed under the Creative Commons Attribution International License (CC BY).

http://creativecommons.org/licenses/by/4.0/

(c) () D Den Access

\section{Abstract}

Globally a large number of process-based models have been assessed for quantification of agricultural greenhouse gas (GHG) emissions. Modelling approaches minimize the presence of spatial variability of biogeochemical processes, leading to improved estimates of GHGs as well as identifying mitigation and policy options. The comparative performance of the three dynamic models (e.g., DNDC v9.4, DailyDayCent and ECOSSE v5+) with minimum numbers of common input parameters was evaluated against measured variables. Simulations were performed on conventionally-tilled spring barley crops receiving $\mathrm{N}$ fertilizer at $135-159 \mathrm{~kg} \cdot \mathrm{N} \cdot \mathrm{ha}^{-1} \cdot \mathrm{yr}^{-1}$ and crop residues at

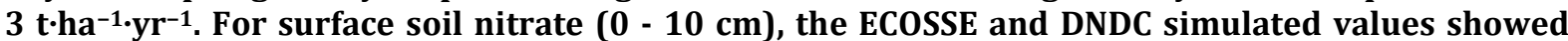
significant correlations with measured values $\left(\mathrm{R}^{2}=0.31-0.55, p<0.05\right)$. Only the ECOSSE-simulated $\mathrm{N}_{2} \mathrm{O}$ fluxes showed a significant relationship $\left(\mathrm{R}^{2}=0.33, p<0.05\right)$ with values measured from fertilized fields, but not with unfertilized ones. The DNDC and DailyDayCent models significantly underestimated seasonal/annual $\mathrm{N}_{2} \mathrm{O}$ fluxes compared to ECOSSE, with emission factors (EFs), based on an 8-year average, were $0.09 \%, 0.31 \%$ and $0.52 \%$, respectively. Predictions of ecosystem respiration by both DailyDayCent and DNDC showed reasonable agreement with Eddy Covariance data $\left(\mathrm{R}^{2}=0.34-0.41, p<0.05\right)$. Compared to the measured value $\left(3624 \mathrm{~kg} \cdot \mathrm{C} \cdot \mathrm{ha}^{-1} \cdot \mathrm{yr}^{-1}\right)$, the ECOSSE underestimated annual heterotrophic respiration by $7 \%$ but this was smaller than the DNDC (50\%) and DailyDayCent (24\%) estimates. All models simulated $\mathrm{CH}_{4}$ uptake well although the ECOSSE

\footnotetext{
${ }^{*}$ Corresponding author.
}

How to cite this paper: Khalil, M.I., Abdalla, M., Lanigan, G., Osborne, B. and Müller, C. (2016) Evaluation of Parametric Limitations in Simulating Greenhouse Gas Fluxes from Irish Arable Soils Using Three Process-Based Models. Agricultural Sciences, 7, 503-520. http://dx.doi.org/10.4236/as.2016.78051 
prediction was closer $\left(-29 \mathrm{~g} \cdot \mathrm{C} \cdot \mathrm{ha}^{-1} \cdot \mathrm{yr}^{-1}\right)$ to the measured one (2.9). The site-specific results imply that the ECOSSE model performed better under Irish conditions. However, further refinement and validation of all of the models with a more extensive dataset that includes other land-use and soil types will be required to determine their suitability in providing national estimates.

\section{Keywords}

\section{Greenhouse Gases, Arable Lands, Input Parameters, Process-Based Models, Ireland}

\section{Introduction}

Agricultural activity is estimated to be responsible for approximately $14 \%$ of global anthropogenic greenhouse gas (GHG) emissions [1]. In the European Union (EU), agriculture comprises $10 \%$ of emissions, with $\mathrm{CH}_{4}$ and $\mathrm{N}_{2} \mathrm{O}$ contributing $49 \%$ and $63 \%$, respectively to sectoral emissions [2]. In the Republic of Ireland (ROI), agricultural emissions comprise one-third of national emissions and remain a key component of national emissions despite recent decreases, due to the economic downturn [3]. Agricultural GHGs, particularly $\mathrm{N}_{2} \mathrm{O}$, are produced mainly through biological processes and the degree of variation (spatial and temporal) in emissions depends on soil type, land use and climatic factors (e.g. [4]-[10]. Agricultural soils may either be net sinks or sources, depending largely on the balance between $\mathrm{N}_{2} \mathrm{O}$ release and carbon (C) sink-source strength and functional relationships exist between organic $\mathrm{C}$ and $\mathrm{N}$, derived from either inorganic or organic sources, to produce GHGs. These relationships are regulated by agricultural activities and associated disturbances (e.g. [11] [12]. Thus, an understanding of the associated controlling factors and their interactions, including impact of site-specific soil conditions are key requirements [13] for understanding the GHG balance and for the development and selection of an appropriate model for accounting and reporting.

Most of the Annex-I countries are using IPCC Tier 1 methodologies [1] [14] [15] for the estimation of agricultural GHGs due to a lack of detailed, spatially-explicit activity data and the absence of disaggregated emission factors (EFs). Some countries (e.g. New Zealand, USA) have moved to Tier 2, with country-specific emission factors and are developing Tier 3 (modelling) methodologies. The Tier 1 approach has several limitations for studies of the GHG balance relevant to Agriculture, Forestry and Other Land Uses (AFOLU)/LULUCF [1]. Development of higher tiers requires good country/regional-specific activity data allied to extensive GHG emissions datasets. Compared to Tier 2, more additional resources are required for the development of Tier 3, including an appropriate biogeochemical model. A process-based model could take into account functional relationships and provide a flexible and structured way to assess how different scenarios including land-use management and land-use change can affect GHG emissions and soil C and N dynamics. A modelling approach can provide improved estimates of GHG budgets and reflect more robust emissions assessments (sink or source) by reducing the uncertainties associated with the impacts of soil, climate and management activities. The advantages in using a model include an ability to 1) scale GHG emissions from the site-specific to the national/regional level, 2) identify potential mitigation options and the interactions between different gaseous and/or other loss pathways, and 3) provide a better understanding of how agricultural soils can act as $\mathrm{C}$ sinks or sources.

In line with commitments under the UNFCCC, the ROI is committed to improving the estimation of GHG budgets by developing Tier 3 approaches. There has been much progress in recent years in developing models to simulate GHG emissions. Modelling is considered a low-cost method of estimating GHG emissions from agricultural soils at different scales and for exploring potential mitigation strategies [16]. Any discrepancies in predicting field measured GHG fluxes can be used to identify limitations to model use, suggesting further potential developments that could lead to a better representation of the impacts of differences in land use, land use management or environmental factors. However, spatial variability in GHG fluxes due to soil heterogeneity, in particular, has to be considered when comparing model results with field measurements [17] [18]. There is also a particular need for improved methodologies for up-scaling of GHG emissions from site to regional/national scales [1]. The use of models for estimating soil GHG emissions is expected to increase, and further improvements in model accuracy and precision will be essential.

Several process-based models are currently used to predict a variety of variables related to different ecosystems. DNDC (DeNitrification-DeComposition) is a process-based model that simulates carbon (C) and nitrogen 
(N) biogeochemistry in agro-ecosystems and has been used for predicting GHG emissions, soil C dynamics, crop growth and other relevant data [19]. DailyDayCent is the daily time-step version of the CENTURY biogeochemical model [20], which simulates daily N-gas fluxes, C fluxes and other ecosystem parameters [21]. More recently, the Rothamsted Carbon Model (RothC) and SUNDIAL (SimUlation of Nitrogen Dynamics in Arable Land) have been used in the development of a multi-pool, process-based model, called "ECOSSE" (Estimating Carbon in Organic Soils-Sequestration and Emissions) [22]. The ECOSSE model simulates soil C and $\mathrm{N}$ turnover, including GHG/trace gas emissions, in both mineral and organic soils using only limited meteorological, land-use and soil data, compared to other models. In the ROI, some models (DNDC, DayCent, RothC, PASIM, etc.) have been tested/validated using limited datasets measured from grassland and arable systems [23]-[29]. However the results have not been sufficiently robust to allow them to be used in the inventory process without further investigations.

Based on the different characteristics and performances, three process-based models (DNDC v9.4, DailyDayCent and ECOSSE v5+) were chosen to evaluate GHG emissions associated with the major Irish cropland type. The goal was to establish the basis of an emission inventory system using process-based models with the minimum number of commonly available input parameters that reflect the site-specific diversity of management practices that influence GHG emissions. Barley, with dominancy of spring barley, is the major cereal crop in Ireland, comprising 71\% of the total cereals in 2014 [30]. Multi-year GHG fluxes data for spring barley, measured at the plot scale, were available to initiate model comparison exercises. The main objectives were: 1) to simulate daily $\mathrm{N}_{2} \mathrm{O}, \mathrm{CH}_{4}$ and $\mathrm{CO}_{2}$ emissions from conventionally-tilled spring barley fields located in Carlow, Ireland over 8 years using the DNDC v9.4, DailyDayCent and ECOSSE v5+ models; 2) to assess the extent of statistical agreements ( $\mathrm{R}^{2}$, RMSE, RE and MD) between model outputs and measured datasets; and 3) to evaluate the differences between the measured and modelled seasonal/annual GHG emissions and their estimated EFs.

\section{Materials and Methods}

\subsection{Experimental Sites and Datasets}

Data on inputs and management practices were collected from plot-scale field experiments conducted at the Teagasc Oak Park Research Centre, Carlow (52 ${ }^{\circ} 86^{\prime} \mathrm{N}$ and 6 6 $\left.54^{\prime} \mathrm{W}\right)$. The soil (0 - $10 \mathrm{~cm}$ depth) at Oak Park site is classified as a sandy loam (overlying loam) in texture, free draining, Euteric Cambisol (Grey Brown Podzolics). Detailed site characteristics, which may differ from other published information [24] [25] [31] due to averaging of samples taken from both small and large plots, are given in Table 1. Thirty years (1982-2011) climate data measured from the nearby weather stations (Oak Park, Carlow and Kilkenny, 30 km away) by Met Eireann were used as inputs to run the models. The meteorological inputs required for DNDC and DailyDayCent are daily minimum and maximum air temperature, rainfall, wind speed, radiation and relative humidity; and for ECOSSE only average air temperature, rainfall and potential evapotranspiration is required.

\subsection{Description of Field Experiments}

The larger plots used (2.5 ha) for field-scale studies were part of an experiment comparing the effects of conventional and minimum tillage practices [24] [25] [32]-[34]. An experiment was also carried out using small plots $\left(6 \mathrm{~m} \times 25 \mathrm{~m}=150 \mathrm{~m}^{2}\right.$, each plot containing a $0.27 \mathrm{~m}^{2}$ ground area chamber), which were on the border of the large plots. Only the results from the conventional (CT) tillage treatment were used in the present paper. The CT plots were prepared using a mouldboard plough to a depth of $22-25 \mathrm{~cm}$. Subsequently, a light tilling was performed in the CT treatment and seeds (spring barley, cv. Tavern/Quench) were sown using a cultivator drill, followed by rolling. The small plots comprised three randomized. Each main plot divided into two subplots containing different fertilizer treatments: fertilized $\left(\mathrm{N}_{1}\right)$ and non-fertilized $\left(\mathrm{N}_{0}\right)$ plots. Treatments were randomly distributed and each treatment was replicated four times.

Following the harvesting of the crop (July or August), crop residues were chopped and left on the field over the autumn and winter period (Table 1). The experiments were conducted under rainfed conditions. $\mathrm{N}$ fertilizer was applied in the form of calcium ammonium nitrate (CAN). The amount of $\mathrm{N}$ applied varied slightly from year to year. From 2004-2006 fertilizer was applied at 0 and $135-159 \mathrm{~kg} \cdot \mathrm{N} \cdot \mathrm{ha}^{-1}$, whilst from 2007-2011 it was applied at 0 and $135 \mathrm{~kg} \cdot \mathrm{N} \cdot \mathrm{ha}^{-1}$. It was split into two applications from 2005 onwards. The unfertilized control started in 2003 and prior to that the whole field had received annually $140-160 \mathrm{~kg} \cdot \mathrm{N} \cdot \mathrm{ha}^{-1}$ and had been in spring barley production since the mid-1990s. Herbicide (glyphosate $3 \mathrm{l} \cdot \mathrm{ha}^{-1}$ of a $360 \mathrm{~g}$ product) was applied in January or early February to control over-wintering weeds and volunteer barley seedlings. 
Table 1. Site characteristics of experimental field as well as inputs and management practices (EC = Eddy Covariance/large plot received highest $\mathrm{N}$ rate).

\begin{tabular}{|c|c|}
\hline \multicolumn{2}{|c|}{ Site characteristics } \\
\hline Location & Oak Park, Carlow \\
\hline Latitude-longitude & $52^{\circ} 86^{\prime} \mathrm{N}-6^{\circ} 54^{\prime} \mathrm{W}$ \\
\hline Mean annual air temperature $\left({ }^{\circ} \mathrm{C}\right)$ & 9.8 \\
\hline Mean annual precipitation (mm) & 870.5 \\
\hline Land use history & $\begin{array}{l}\text { Cereals (15 years), croplands (50 years), received } 140-160 \mathrm{~kg} \cdot \mathrm{N} \cdot \mathrm{ha}^{-1} \\
\text { in } 2003 \text { and the year before. Spring barley since } 2000 .\end{array}$ \\
\hline Soil type (FAO/Irish GSG) & Euteric Cambisol/Grey Brown Podzolics \\
\hline Soil texture: 0 - 10/0 - $25 \mathrm{~cm}$ & Sandy loam \\
\hline Clay (\%): 0 - 10/0 - $25 \mathrm{~cm}$ & $15.13 / 14.73$ \\
\hline Silt (\%): 0 - 10/0 - $25 \mathrm{~cm}$ & $25.63 / 33.73$ \\
\hline Sand (\%): 0 - 10/0 - $25 \mathrm{~cm}$ & $59.24 / 51.55$ \\
\hline Bulk density $\left(\mathrm{g} \cdot \mathrm{m}^{-3}\right): 0-10 / 0-25 \mathrm{~cm}$ & $1.42 / 1.46$ \\
\hline Total soil organic carbon $\left(\mathrm{kg} \cdot \mathrm{ha}^{-1}\right): 0$ - $10 / 0$ - $25 \mathrm{~cm}$ & $19.912 / 42.888$ \\
\hline $\begin{array}{l}\text { Total inert soil organic carbon }\left(\mathrm{kg} \cdot \mathrm{ha}^{-1}\right) \text { : } \\
\qquad 0-10 / 0-25 \mathrm{~cm}\end{array}$ & $3.863 / 8.163$ \\
\hline Soil pH: 0 - 10/0 - 25 cm & $7.24 / 7.35$ \\
\hline $\begin{array}{l}\text { Available water (AW) at field capacity (mm): } \\
\qquad 0-10 / 0-25 \mathrm{~cm}\end{array}$ & $22.69 / 55.13$ \\
\hline Water content at saturation (\%): 0 - 10/0 - 25 cm & $47.21(\mathrm{AW}=29.51 \mathrm{~mm}) / 45.56=113.87 \mathrm{~mm}(\mathrm{AW}=71.17)$ \\
\hline Water content at field capacity (\%): 0 - 10/0 - $25 \mathrm{~cm}$ & $40.39(\mathrm{AW}=22.69 \mathrm{~mm}) / 38.97=97.43 \mathrm{~mm}(\mathrm{AW}=54.73 \mathrm{~mm})$ \\
\hline Water content at wilting point (\%): 0 - 10/0 - 25 cm & $17.70(=17.70 \mathrm{~mm}) / 17.08=42.7 \mathrm{~mm}$ \\
\hline Initial $\mathrm{NH}_{4}$ and $\mathrm{NO}_{3}{ }^{-}\left(\mathrm{kg} \cdot \mathrm{N} \cdot \mathrm{ha}^{-1}\right): 0-10 / 0-25 \mathrm{~cm}$ & 2.8/6.9 and $9.5 / 23.17$ \\
\hline Annual atmospheric $\mathrm{N}$ deposition $\left(\mathrm{kg} \cdot \mathrm{ha}^{-1}\right)$ & 11 \\
\hline Slope (\%) and water table depth (cm) & 0.004\% from vertical and 240 \\
\hline Depth of impermeable layer $(\mathrm{cm})$ and drainage class & $>150$ and High \\
\hline
\end{tabular}

\begin{tabular}{|c|c|}
\hline \multicolumn{2}{|r|}{ Inputs and management practices } \\
\hline Land use & Spring barley (var. Tavern or Quench) \\
\hline Date of previous crop harvested & $17 / 08 / 03$ \\
\hline Type and depth of tillage practices & Conventional (22 - $25 \mathrm{~cm})$ \\
\hline Date of tillage practices (ploughed and light till) & $\begin{array}{c}\text { 19/02/04 and 25/03/04; 09/03/05 and } 14 / 03 / 05 ; 10 / 03 / 06 \text { and } 19 / 03 / 06 ; 24 / 02 / 07 \text { and } \\
\text { 18/03/07; 22/02/08 and 19/03/08; } 18 / 02 / 09 \text { and 18/03/09; 02/03/10 and 08/03/10; } \\
\text { 02/03/11 and 08/03/11 }\end{array}$ \\
\hline Date of sowing & 26/03/04; 16/03/05; 20/03/06; 21/03/07; 20/03/08; 19/03/09; 09/03/10; 09/03/11 \\
\hline Residue incorporation & $\begin{array}{c}3.0 \mathrm{t} \cdot \mathrm{DM} \cdot \mathrm{ha}^{-1}\left(1.32 \mathrm{t} \cdot \mathrm{C} \cdot \mathrm{ha}^{-1}\right) \text {, chopped and left on the field; incorporated during } \\
\text { tillage operation only }\end{array}$ \\
\hline Type of $\mathrm{N}$ fertilizer & Calcium Ammonium Nitrate (CAN) \\
\hline Number of fertilizer application & 2003-04: 1; 2005-11: 2 \\
\hline Fertilizer $\mathrm{N}$ rates $\left(\mathrm{kg} \cdot \mathrm{N} \cdot \mathrm{ha}^{-1}\right)$ & $\begin{array}{c}\text { 2003: 140; 2004: } 0 \text { and 140; 2005: } 0 \text { and } 159(106+53) ; 2006: 0 \text { and } 140(90+50) \text {; } \\
\text { 2007-2011: } 0 \text { and } 135(67.5+67.5)\end{array}$ \\
\hline Date of fertilizer application & $\begin{array}{l}\text { 27/04/04; } 12 / 04 / 05 \text { and } 10 / 05 / 05 ; 12 / 04 / 06 \text { and } 11 / 05 / 06 ; 20 / 04 / 07 \text { and } 10 / 05 / 07 \text {; } \\
16 / 04 / 08 \text { and 15/05/08; 21/04/09 and 22/05/09; 13/04/10 and 07/05/10; 04/04/11 and } \\
10 / 05 / 11\end{array}$ \\
\hline Date of harvest & $\begin{array}{c}\text { 17/08/03; 17/08/04; 09/08/05; 09/08/06; 17/07/07; 22/08/08; 12/08/09; 06/08/10; } \\
14 / 08 / 11\end{array}$ \\
\hline
\end{tabular}




\subsection{Measurements of $\mathrm{N}_{2} \mathrm{O}, \mathrm{CO}_{2}$ and $\mathrm{CH}_{4}$}

Measurements of GHGs from the experimental plots were either made seasonally or annually and for three years commencing from 2009 to 2011, at daily or fortnightly intervals. $\mathrm{N}_{2} \mathrm{O}$ emissions were measured using the static closed chamber method. Gas was sampled at 0, 30 and 60 min intervals between 9 and 11 am every week and more intensively (twice weekly) following fertilizer application. The gas samples were stored in exetainers (Labco, High Wycombe, UK) prior to the analyses. The gas analyses were performed using a gas chromatography (Varian CP 3800 GC, Varian, USA) fitted with a 63Ni electron capture detector (ECD) for $\mathrm{N}_{2} \mathrm{O}$ analysis and a Flame Ionisation Detector (FID) for $\mathrm{CH}_{4}$ analysis with high purity helium as a carrier gas. Samples were returned to ambient pressure prior to analysis and fed into the system by a Combi-Pal automatic sampler (CTC Analysis, Switzerland). Following a two-year gap, gas samples for the measurement of both $\mathrm{N}_{2} \mathrm{O}$ and $\mathrm{CH}_{4}$ were collected from September 2008 to September 2010 and from April 2009 to September 2010, respectively. Gas sampling was carried out weekly during the crop growth period and less frequently (2 - 3 weeks) during the fallow period using static chambers, with 18 replicates.

Eddy Covariance (EC) systems installed in the large plots, consisted of Gill R3 sonic anemometer (Gill Instruments, USA) and Li-7000 infra-red gas analyser (Licor Inc., USA), for net ecosystem exchange (NEE) and ecosystem respiration $\left(R_{\text {eco }}\right)$ measurements. Estimates of $R_{\text {eco }}(2003-2007)$ were based on half-hourly measurements and expressed on a daily basis.

\subsection{Determination of Soil Nitrate Concentrations}

Soils were sampled during the gas sampling periods and soil nitrate concentrations were determined on $2 \mathrm{M} \mathrm{KCl}$ extracts using an auto-analyzer (Bran and Luebbe, Norderstedt, Germany) [35].

\subsection{Description of Models}

Three dynamic models (ECOSSE v5 updated in 2012, DNDC v9.4 and DailyDayCent) were selected for this comparative study. Input requirements for each model differ as indicated previously. However, the site characteristics and crop management practices used were the same for all the models which were run for 8 years. Other inputs were either defaults or module-based. A brief description of the models is given below. ECOSSE was mainly calibrated under UK conditions [36] with subsequent improvements of the $\mathrm{N}_{2} \mathrm{O}$ and $\mathrm{CH}_{4}$ modules using Irish data [37]. Both DNDC and the DailyDayCent were calibrated/validated under Irish conditions [24] [32] [33].

\subsubsection{ECOSSE Model}

The ECOSSE model was developed to simulate SOC in highly organic soils from algorithms originally derived for mineral soils in the RothC and SUNDIAL models [22] [38]. The model uses a pool type approach, and all of the major processes of $\mathrm{C}$ and $\mathrm{N}$ turnover in the soil are included and are driven by readily available input variables (e.g., SOC, soil water, plant inputs, nutrient applications and timing of management operations). It is a tool for site-specific simulations that apparently does not result in any major loss in accuracy at this scale and makes full use of the limited information that is available to run models whilst still providing accurate simulations of GHGs. The $\mathrm{N}_{2} \mathrm{O}$ fluxes derive from both nitrification and denitrification, $\mathrm{CO}_{2}$ corresponds to $\mathrm{R}_{\mathrm{H}}$ and $\mathrm{CH}_{4}$ through a balance between methanogenesis and methanotrophy and changes in SOC stocks. The model can be used with both organic and mineral soils, to provide estimates of the net change in soil $\mathrm{C}$ and $\mathrm{N}$ in response to changes in land use and climate. This model considers variations for outputs by calculating them on each soil layer for each time step. This model doesn’t use crop growth parameters as inputs but uses a built-in default functional relation.

\subsubsection{DNDC Model}

The DNDC is a widely used process-based model [39] [40], but several modifications/versions have been developed for different production systems. This model couples denitrification and decomposition processes to predict emissions of $\mathrm{C}$, with $\mathrm{CH}_{4}$ oxidation, and $\mathrm{N}$ from agricultural soils that are governed by various soil and environmental factors. It contains six sub models: soil climate, crop growth, decomposition, denitrification, nitrification and fermentation, and includes subroutines for cropping practices (fertilization, irrigation, tillage, crop rotation and manure addition) to simulate SOM turnover. The model considers decomposition process as first order kinetics, and the soil is considered as a series of discrete horizontal layers with uniform soil properties within each layer, except for some soil physical properties that are anticipated as being constant across all layers. 
However, time-dependent variations in soil moisture, temperature, $\mathrm{pH}, \mathrm{C}$ and $\mathrm{N}$ pools are considered for a reliable estimate of $\mathrm{C}$ and $\mathrm{N}$ fluxes by calculating them for each soil layer for each time step.

\subsubsection{DailyDayCent Model}

DailyDayCent is a biogeochemical model based on the Century soil C model and, for the most part, the parameter files used are identical to the ones used by Century 4.5 and DayCent 4.5 [41] [42]. This model simulates C and $\mathrm{N}$ fluxes between the atmosphere, vegetation, and soil. Major factors (e.g. nutrient availability, water, temperature) controlling plant growth are included in order to simulate GHGs and SOC changes over time. This model considers nutrient supply as a function of SOM decomposition and external nutrient additions. Other model inputs are the timing and description of management events (e.g. fertilization, tillage, harvest), and soil texture data. There are submodels that consider plant production, SOM decomposition, soil water and temperature for each layer, as well as nitrification and denitrification, and $\mathrm{CH}_{4}$ oxidation. Improvements in this model are on-going, and comparison of model results and plot data have shown that DayCent reliably simulates crop yield, SOM levels, and trace gas fluxes for various native and managed systems [43].

\subsection{Model Run, Statistical Evaluation and Calculation}

The datasets were collated and compiled to prepare a list of common input parameters with respect to site characteristics and managements to initialize the models (Table 1). The models were run using the common input parameters and the weather data (data not shown). For DNDC and DailyDaycent, the corresponding simulation spin-up for 30 and 700 years were used to allow the model to reach equilibrium state. For ECOSSE, the soil C pool at steady state equilibrium, with crop residue inputs and $\mathrm{N}$ as the $\mathrm{NO}_{3}^{-}$concentration measured immediately before the start of experiments was used for the initialization.

The ECOSSE model can predict soil heterotrophic respiration $\left(\mathrm{R}_{\mathrm{H}}\right)$ only whereas the EC provides $\mathrm{R}_{\text {eco }}$ (soil autotrophic and heterotrophic respiration + crop respiration). For comparison and validation of ECOSSE-simulated $\mathrm{R}_{\mathrm{H}}$ with measured ones, daily $\mathrm{R}_{\mathrm{eco}}$ measured by $\mathrm{EC}$ from the large fertilized plot was transformed to daily $\mathrm{R}_{\mathrm{H}}$ using DailyDayCent fractions $\left(\mathrm{R}_{\mathrm{H}} / \mathrm{R}_{\text {eco }}\right)$ obtained from this study. Calculation of the total/cumulative $\mathrm{N}_{2} \mathrm{O}$, $\mathrm{R}_{\mathrm{H}}$ and $\mathrm{R}_{\text {eco }}$ through integration of the measurement values and the sum of simulated values were performed. Seasonal and annual emission factors (EFs) for $\mathrm{N}_{2} \mathrm{O}$ over the 8 years were calculated by subtracting cumulative measured and model outputs of the unfertilized control from that of the fertilized treatments and dividing by the respective $\mathrm{N}$ inputs.

The outputs were collated and converted into standard units for comparison with measured datasets. The simulated values of GHGs were compared and validated quantitatively with measured values using MS Excel speadsheet (MODEVAL v 2.0) [44]. Based on the available measured flux data, an evaluation of the consistency of seasonal (4 - 5 months)/annual $\mathrm{N}$ and $\mathrm{C}$ emissions with simulated values was carried out. The approach was to take a simple mean and standard error (SE) of the values for each dataset and to calculate statistics (e.g., $\mathrm{R}^{2}=$ Coefficient of determination; RMSE = Root Mean Square Error; RE = Relative Error; MD = Mean Difference) that describe the model fits for all data points simulated by placing equal weight on all values. An analysis of variance for significance at the 0.05 level of probability was performed and the $95 \%$ confidence intervals calculated using SAS v. 9.3 (SAS Inc.), MODEVAL and MS Excel (v. 2010).

\section{Results}

\subsection{Simulated and Measured Nitrate-N Concentrations}

The measured surface soil $\mathrm{NO}_{3}^{-}$concentration was found to reach a maximum of $71.3 \mathrm{~kg} \cdot \mathrm{N} \cdot \mathrm{ha}^{-1}$ following fertilization, decreasing to $0.82 \mathrm{~kg} \cdot \mathrm{N} \cdot \mathrm{ha}^{-1}$ during later periods (Figure 1). In the unfertilized field, the minimum and maximum surface $\mathrm{NO}_{3}^{-}$levels (seasonal/annual) measured was 0.20 and $25.2 \mathrm{~kg} \cdot \mathrm{N} \cdot \mathrm{ha}{ }^{-1}$, respectively. The DailyDayCent and DNDC-predicted soil $\mathrm{NO}_{3}^{-}$levels were highly variable. For the fertilized field, the average $\mathrm{NO}_{3}^{-}$contents predicted over the 8 years by DailyDayCent $\left(71 \pm 1.6 \mathrm{~kg} \cdot \mathrm{N} \cdot \mathrm{ha}^{-1}\right)$ and DNDC $\left(193 \pm 4.6 \mathrm{~kg} \cdot \mathrm{N} \cdot \mathrm{ha}^{-1}\right)$ were markedly higher than the ECOSSE simulated $\left(20 \pm 0.4 \mathrm{~kg} \cdot \mathrm{N} \cdot \mathrm{ha}^{-1}\right)$ values or the measured ones. For the unfertilized field, the corresponding average surface $\mathrm{NO}_{3}^{-}$concentrations predicted were $12 \pm 0.2,17 \pm 0.4$ and $8 \pm 0.1 \mathrm{~kg} \cdot \mathrm{N} \cdot \mathrm{ha}^{-1}$. Only the ECOSSE model predicted values that were closer to measured values, which were consistent over the 8 years, and to the amount of $\mathrm{NO}_{3}^{-}$applied. For the fertilized field, the ECOSSE $\left(\mathrm{R}^{2}=0.55\right)$ 

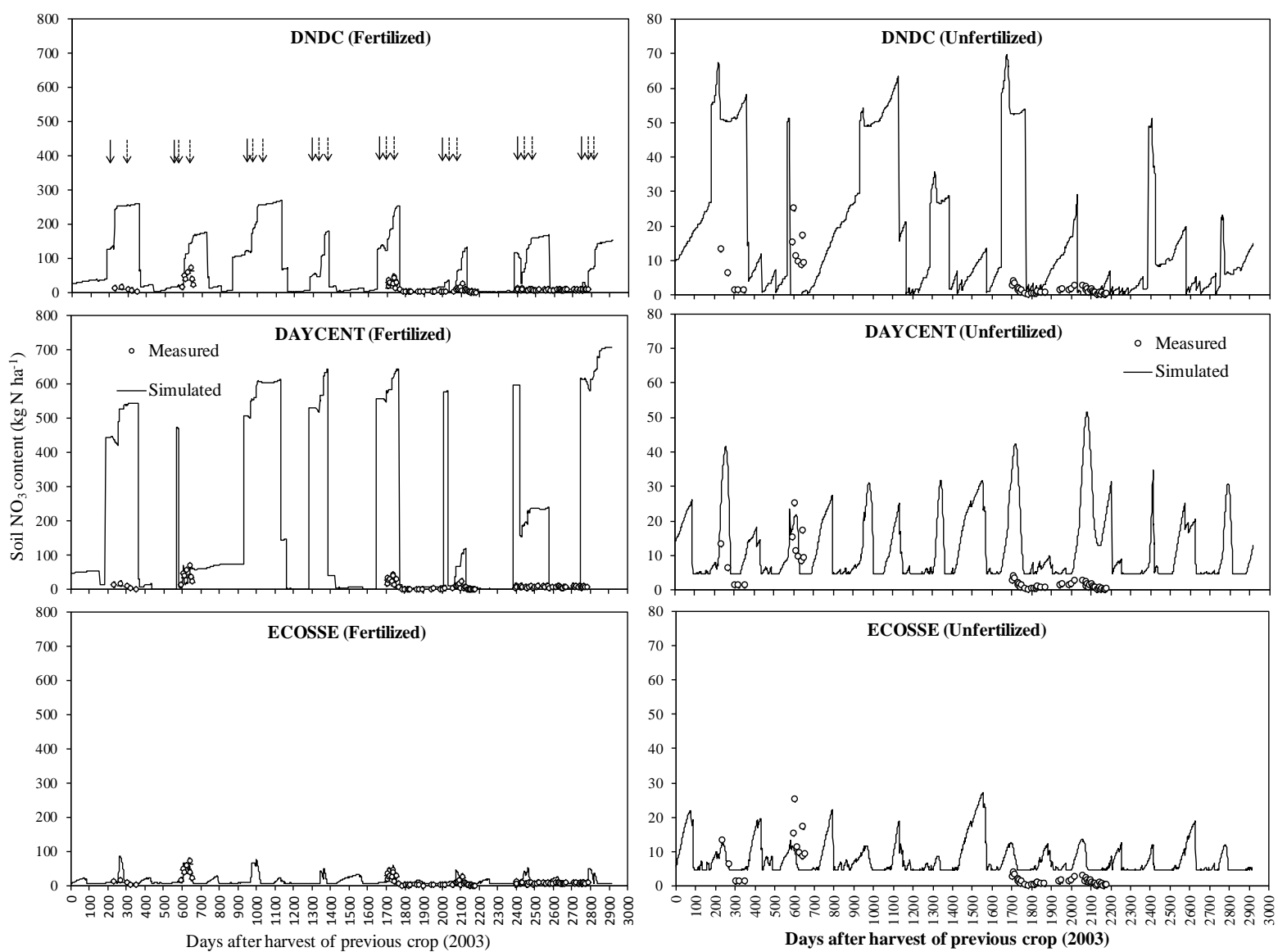

Figure 1. Comparison of field measured (seasonal/annual; open circle/square with vertical bars as standard errors) nitrate-N concentrations $\left(\mathrm{kg} \cdot \mathrm{N} \cdot \mathrm{ha}^{-1}\right.$ ) in the $0-10 \mathrm{~cm}$ soil depth with values simulated (solid line) using the three process-based models over 8 years, commencing from 17 August 2003 (day of harvest), in conventionally-tilled fertilized arable land cropped to spring barley. Solid arrows indicate the days of ploughing and dotted arrows indicate the days of $\mathrm{N}$ fertilizer application.

and the DNDC $\left(\mathrm{R}^{2}=0.31\right)$ model estimates correlated significantly $(p<0.05)$ with the measured values (Table 2). None of the models simulated the surface soil $\mathrm{NO}_{3}^{-}$concentrations for the unfertilized field accurately, showing poor coefficients of determination $\left(\mathrm{R}^{2}=-0.07\right.$ to 0.13$)$. The total error and bias differences between the simulated and measured soil $\mathrm{NO}_{3}^{-}$concentrations were large and significantly $(p<0.05)$ greater than their 95\% confidence intervals for both fields.

\subsection{Performance of Models to Simulate GHG Emissions}

\subsection{1. $\mathrm{N}_{2} \mathrm{O}$ Emissions}

The maximum $\mathrm{N}_{2} \mathrm{O}$ flux measured across all years was observed in $2004\left(56.0 \mathrm{~g} \cdot \mathrm{N} \cdot \mathrm{ha} \mathrm{a}^{-1} \cdot \mathrm{d}^{-1}\right.$ ) (Figure 2). For the other years the maximum value was $17.6 \mathrm{~g} \cdot \mathrm{N} \cdot \mathrm{ha}^{-1} \cdot \mathrm{d}^{-1}$ and the minimum $-8.0 \mathrm{~g} \cdot \mathrm{N} \cdot \mathrm{h} \mathrm{a}^{-1} \cdot \mathrm{d}^{-1}$, demonstrating small differences with the unfertilized plot (16.6 versus $-10.4 \mathrm{~g} \cdot \mathrm{N} \cdot \mathrm{ha}^{-1} \cdot \mathrm{d}^{-1}$ ). Regardless of the models, the simulated $\mathrm{N}_{2} \mathrm{O}$ fluxes were consistent over the years but differed from the measured values, and none of the models predicted fluxes less than zero. The $\mathrm{N}_{2} \mathrm{O}$ fluxes varied largely between the fertilized $\left(80.0-100.9 \mathrm{~g} \cdot \mathrm{N} \cdot \mathrm{ha}^{-1} \cdot \mathrm{d}^{-1}\right)$ and unfertilized (24.5 - $\left.56.5 \mathrm{~g} \cdot \mathrm{N} \cdot \mathrm{ha}^{-1} \cdot \mathrm{d}^{-1}\right)$ plots, with the highest values predicted by DailyDayCent, including an unusual peak for the unfertilized field $\left(110.1 \mathrm{~g} \cdot \mathrm{N} \cdot \mathrm{ha}^{-1} \cdot \mathrm{d}^{-1}\right)$. The ECOSSE-simulated values correlated well with the measured values $\left(\mathrm{R}^{2}=0.33, p<0.05\right)$ under fertilized conditions only (Table 2$)$. The total bias and error differences between simulated and measured values did not vary significantly with their $95 \%$ confidence levels. Similar results were observed for the unfertilized field but the coefficient of determination was poor $\left(\mathrm{R}^{2}=-0.02\right.$ to -0.04 , negative).

For the fertilized fields, both DNDC (87\%) and DailyDayCent (81\%) underestimated the total $\mathrm{N}_{2} \mathrm{O}$ fluxes 
Table 2. Statistical comparison between simulated and the measured daily soil $\mathrm{NO}_{3}{ }^{-}$concentration $\left(\mathrm{kg} \cdot \mathrm{N} \cdot \mathrm{ha}{ }^{-1}\right)$ and $\mathrm{N}_{2} \mathrm{O}$ fluxes $\left(\mathrm{g} \cdot \mathrm{N} \cdot \mathrm{ha}^{-1}\right.$ ) from a conventionally-tilled plot cropped to spring barley.

\begin{tabular}{|c|c|c|c|c|c|c|}
\hline \multirow{2}{*}{ Statistical parameters } & \multicolumn{3}{|c|}{ Fertilized } & \multicolumn{3}{|c|}{ Unfertilized (Control) } \\
\hline & DNDC & DailyDayCent & ECOSSE & DNDC & DailyDayCent & ECOSSE \\
\hline \multicolumn{7}{|c|}{ Soil $\mathrm{NO}_{3}{ }^{-}$concentration } \\
\hline $\mathrm{R}^{2}$ & $0.31^{*}$ & 0.14 & $0.55^{*}$ & -0.07 & 0.00 & 0.13 \\
\hline RMSE (\%) & $925^{*}$ & $2847^{*}$ & $115^{*}$ & $837^{*}$ & $684^{*}$ & $169^{*}$ \\
\hline RMSE $_{95 \%}(\%)$ & 103 & 103 & 103 & 157 & 157 & 157 \\
\hline RE (\%) & $-610^{*}$ & $-1807^{*}$ & $-46^{*}$ & $-419^{*}$ & $-497^{*}$ & $-86^{*}$ \\
\hline $\mathrm{RE}_{95 \%}(\%)$ & 66 & 66 & 66 & 65 & 65 & 65 \\
\hline MD (\%) & -68 & -203 & -5 & -14 & -16 & -3 \\
\hline \multicolumn{7}{|c|}{$\mathrm{N}_{2} \mathrm{O}$ fluxes } \\
\hline $\mathrm{R}^{2}$ & -0.02 & 0.19 & $0.33^{*}$ & -0.02 & -0.03 & -0.04 \\
\hline RMSE (\%) & 189 & 367 & 154 & 186 & 183 & 197 \\
\hline $\mathrm{RMSE}_{95 \%}(\%)$ & 372 & 372 & 372 & 305 & 305 & 305 \\
\hline $\mathrm{RE}(\%)$ & 87 & 74 & -59 & 94 & 87 & -43 \\
\hline $\mathrm{RE}_{95 \%}(\%)$ & 267 & 267 & 267 & 305 & 305 & 305 \\
\hline MD (\%) & $5^{*}$ & $4^{*}$ & -3 & $2^{*}$ & $2^{*}$ & -1 \\
\hline
\end{tabular}

${ }^{*}$ Significant at $5 \%$ level of probability. $\mathrm{R}^{2}=$ Coefficient of Determination; RMSE = Root Mean Square Error; RE = Relative Error (Mean); $\mathrm{MD}=$ Mean Difference; $n=130$.
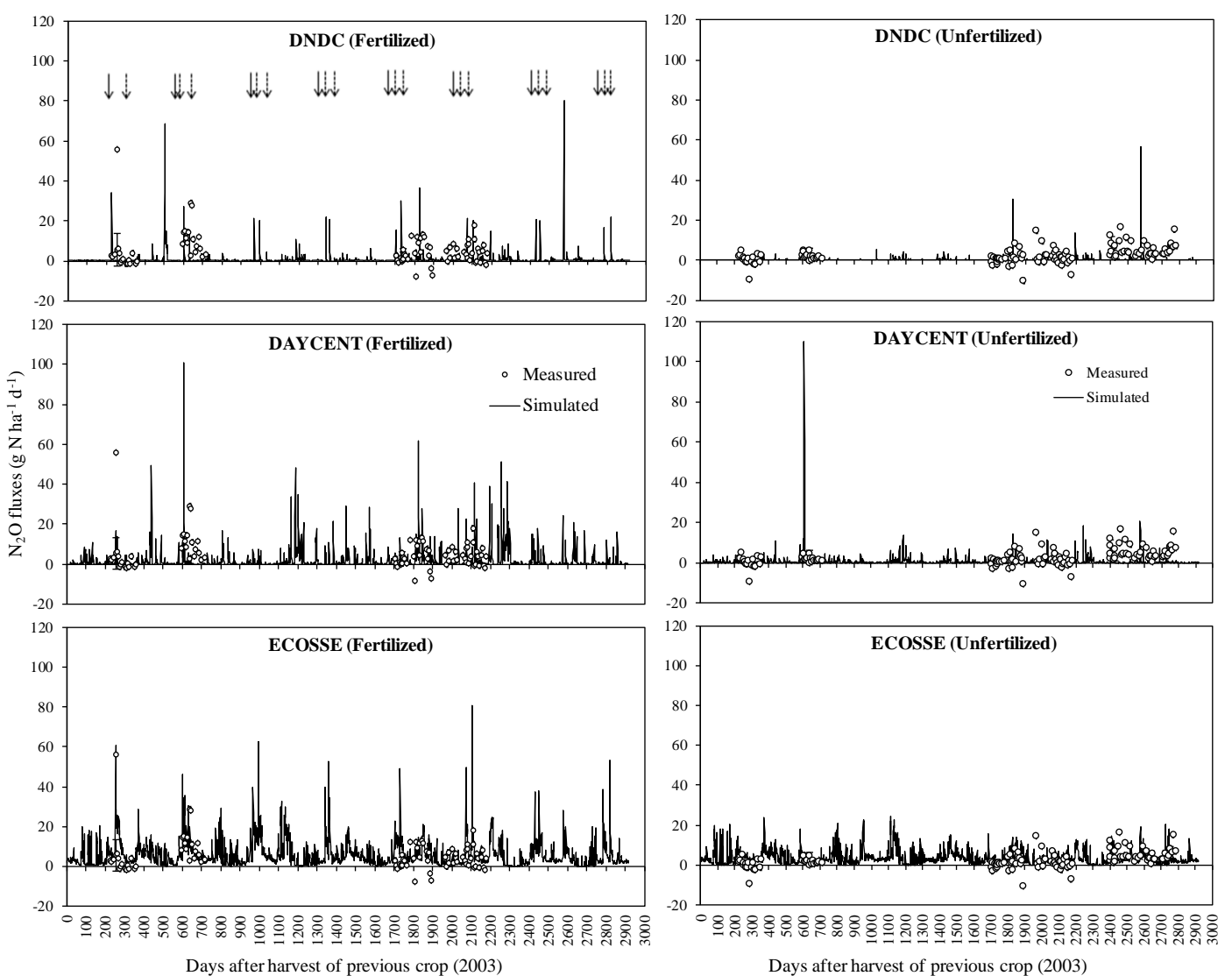

Figure 2. Comparison of field measured (seasonal/annual; open circle/square with vertical bars as standard errors) $\mathrm{N}_{2} \mathrm{O}$ emissions $\left(\mathrm{g} \cdot \mathrm{N} \cdot \mathrm{ha}^{-1}\right.$ ) with values simulated (line) using the three process-based models over 8 years, commencing from 17 August 2003 (day of harvest), in conventionally-tilled fertilized arable land cropped to spring barley. Solid arrows indicate the days of ploughing and dotted arrows indicate the days of $\mathrm{N}$ fertilizer application. 
(seasonal/annual), whilst the ECOSSE model overestimated these by 59\% (Table 3). Based on an 8-year average, the DNDC simulated total $\mathrm{N}_{2} \mathrm{O}$ fluxes for the fertilized $\left(207 \mathrm{~kg} \cdot \mathrm{N} \cdot \mathrm{ha}^{-1}\right)$ and unfertilized $\left(81 \mathrm{~kg} \cdot \mathrm{N} \cdot \mathrm{ha}^{-1}\right)$ fields were 2 - 15 times lower than the estimates provided by the other two models. The DNDC-simulated values resulted in significant underestimation of $\mathrm{N}_{2} \mathrm{O}$ EFs, whilst those derived from DailyDayCent, and the ECOSSE were closer to those calculated from measured values. Compared to the annual EFs derived from measured values, DNDC was 94\% lower, DailyDayCent 44\% lower, and ECOSSE 35\% lower. An estimation discrepancy for total fluxes between integrated values and the corresponding sum of daily fluxes and thereby EFs was observed. On an 8-year average, the simulated $\mathrm{N}_{2} \mathrm{O}$ EF was $0.09 \%$ with DNDC, $0.31 \%$ with DailyDayCent and $0.52 \%$ with the ECOSSE model.

\subsubsection{Ecosystem and Heterotrophic Respiration}

The $\mathrm{R}_{\text {eco }}$ measured using EC from the large fertilized plot reached a maximum flux of $75.6 \mathrm{~kg} \cdot \mathrm{C} \cdot \mathrm{ha}^{-1} \cdot \mathrm{d}^{-1}$ during crop growth that decreased to $0.59 \mathrm{~kg} \cdot \mathrm{C} \cdot \mathrm{ha}^{-1} \cdot \mathrm{d}^{-1}$ during the non-crop period, corresponding to $\mathrm{R}_{\mathrm{H}}$ (Figure 3 ). The DNDC simulated values for $\mathrm{R}_{\text {eco }}$ showed trends similar to the measured values, with an $\mathrm{R}^{2}$ of 0.34 ( $p<$ 0.05 ), and the total bias and error differences between simulated and measured values were $\leq 34 \%$ and $\leq 91 \%$, respectively (Table 4). The estimated $\mathrm{R}_{\text {eco }}$ for the DailyDayCent model also showed trends similar to the measured values, with higher fluxes from 2007 onwards, with an $\mathrm{R}^{2}$ of $0.41(p<0.05)$ and relatively small total bias $(\leq 50 \%)$ and error $(\leq 85 \%)$ difference between simulated and measured values. All models simulated $\mathrm{R}_{\mathrm{H}}$ satisfactorily, with $\mathrm{R}^{2}$ ranging from $0.44-0.62(p<0.05)$, with a small bias $(\leq 50 \%)$ and error $(\leq 87 \%)$ difference between simulated and measured values.

The annual total $\mathrm{R}_{\text {eco }}$ measured using the EC was on average $6771 \mathrm{~kg} \cdot \mathrm{C} \cdot \mathrm{ha}^{-1}$, which is closer to the DailyDayCent value (6736) but higher than the DNDC estimate (4455; Table 4). Based on a 4-year average, the estimated $\mathrm{R}_{\mathrm{H}}$ based on measured values of $\mathrm{R}_{\text {eco }}$ was $3624 \mathrm{~kg} \cdot \mathrm{C} \cdot \mathrm{ha}^{-1}$, which is closer to the ECOSSE and the DailyDayCent simulated values, but higher than the DNDC estimate $\left(1794 \mathrm{~kg} \cdot \mathrm{C} \cdot \mathrm{ha}^{-1}\right)$. Based on an 8-year average, the $\mathrm{R}_{\mathrm{H}}$ differed somewhat from the 4-year average though the simulated amount was similar to the measured value.

\subsection{3. $\mathrm{CH}_{4}$ Fluxes}

The measured $\mathrm{CH}_{4}$ fluxes (emission and oxidation) were small and differed significantly between the fertilized $\left(-040\right.$ to $\left.0.36 \mathrm{~g} \cdot \mathrm{C} \cdot \mathrm{ha}^{-1} \cdot \mathrm{d}^{-1}\right)$ and unfertilized $(-0.09$ to 0.12$)$ plots (Figure 4$)$. The highest simulated oxidation and emission, respectively, were 2.92 and $0 \mathrm{~g} \cdot \mathrm{C} \cdot \mathrm{ha}^{-1} \cdot \mathrm{d}^{-1}$ with DNDC, 4.02 and 0 with DailyDayCent, and 0.24 and 0.31 with ECOSSE, providing values closer to the measured ones for the fertilized plot only. The DNDC and the DailyDayCent simulated values correlated poorly with the measured values $\left(R^{2}=0.02\right)$, demonstrating

Table 3. Statistical comparison between simulated and the measured seasonal and annual $\mathrm{N}_{2} \mathrm{O}$ fluxes (g.N.ha ${ }^{-1}$ ) and emission factors (EFs) derived from a conventionally-tilled field cropped to spring barley.

\begin{tabular}{ccccccccc}
\hline \multirow{2}{*}{ Total $\mathrm{N}_{2}$ O fluxes } & \multicolumn{9}{c}{ Fertilized } & \multicolumn{3}{c}{ Unfertilized (Control) } \\
\cline { 2 - 8 } & Measured & DNDC & DailyDayCent & ECOSSE & Measured & DNDC & DailyDayCent & ECOSSE \\
\hline Seasonal (04) & 522 & 137 & 94 & 1091 & -20 & 18 & 83 & 816 \\
Seasonal (05) & 1145 & 33 & 74 & 1066 & 194 & 2 & 64 & 342 \\
Annual (08 - 09) & 1168 & 88 & 380 & 2049 & 689 & 61 & 119 & 1423 \\
Annual (8 yrs Av) & - & 207 & 644 & 2037 & - & 81 & 218 & 1319 \\
\hline & & & & $\mathrm{N}_{2} \mathrm{O}$ EFs & & & \\
Seasonal (04) & 0.39 & 0.09 & 0.01 & 0.20 & & & & \\
Seasonal (05) & 0.60 & 0.02 & 0.01 & 0.46 & & & \\
Annual (08 - 09) & 0.34 & 0.02 & 0.19 & 0.46 & & & \\
Annual (08 - 09) & - & 0.06 & 0.34 & 0.48 & & & \\
Annual (8 yrs Av) & - & 0.09 & 0.31 & 0.52 & & & \\
\hline
\end{tabular}

"Integrated (harvest to harvest); ${ }^{* *}$ Sum of daily simulated values (harvest to harvest); EF = Emission factor. 

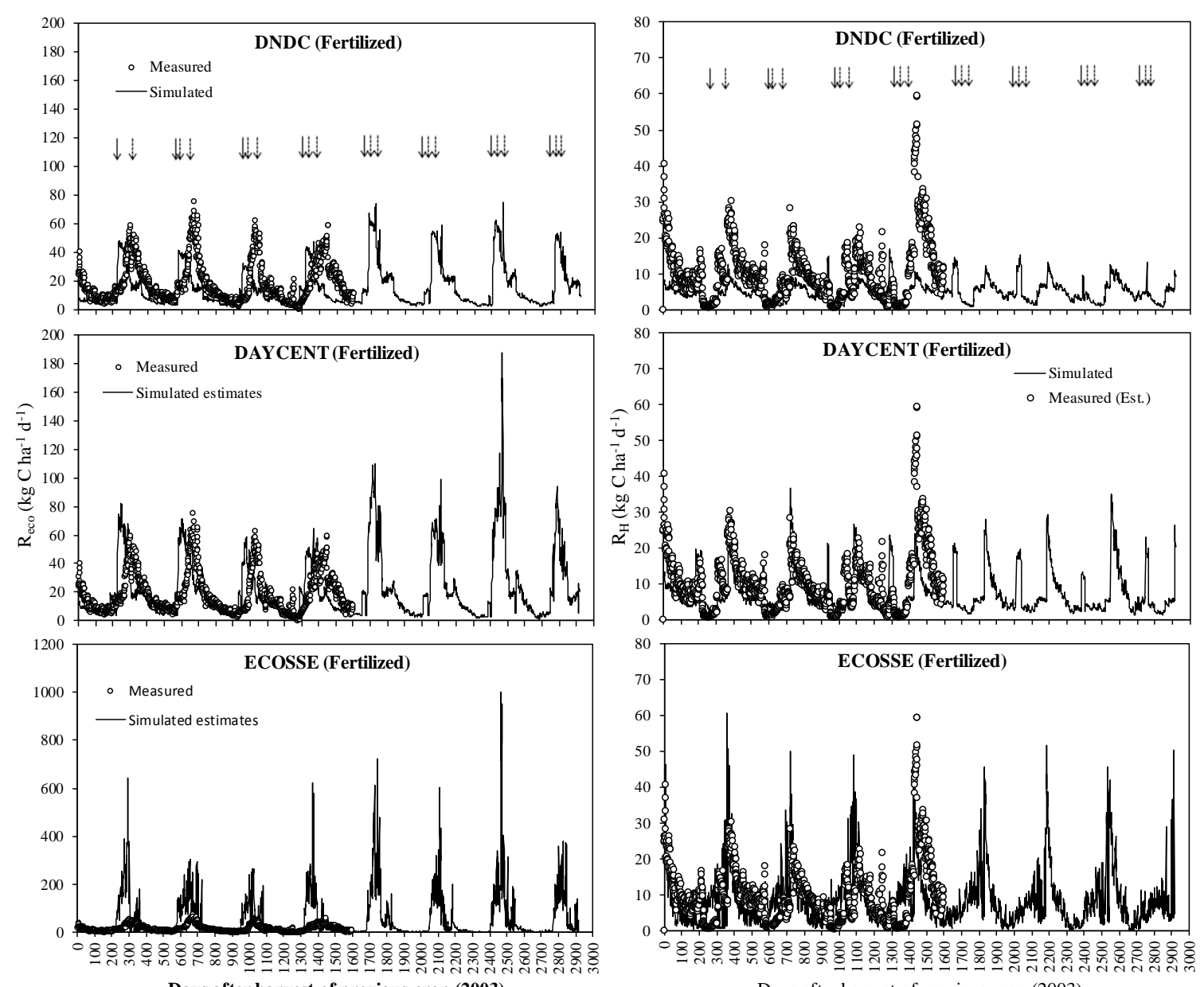

Figure 3. Comparison of Eddy Covariance measured (3 years; open circle) $\mathrm{CO}_{2}$ emissions ( $\mathrm{R}_{\text {eco, }}$ soil respiration only; $\mathrm{kg} \cdot \mathrm{C} \cdot \mathrm{ha}^{-1}$ ) with values simulated (and/or estimated using DNDC-derived fractions for DailyDayCent and ECOSSE; lines, solid/dotted including $\mathrm{R}_{\mathrm{H}}$, heterotrophic respiration) using the three process-based models over 8 years, commencing from 17 August 2003 (day of harvest), in conventionally-tilled fertilized arable land cropped to spring barley. Solid arrows indicate the days of ploughing and dotted arrows indicate the days of $\mathrm{N}$ fertilizer application.

Table 4. Validation of daily soil $\left(\mathrm{R}_{\mathrm{eco}}\right)$ and heterotrophic respiration $\left(\mathrm{R}_{\mathrm{H}}\right)$ simulated by three process-based models with values measured from spring barley fields.

\begin{tabular}{|c|c|c|c|c|c|c|c|c|}
\hline \multirow{2}{*}{ Statistical parameters } & \multicolumn{4}{|c|}{$\mathrm{R}_{\text {eco }}$} & \multicolumn{4}{|c|}{$\mathrm{R}_{\mathrm{H}}$} \\
\hline & Measured & DNDC & DailyDayCent & ECOSSE & Measured! & DNDC & DailyDayCent & ECOSSE $\phi$ \\
\hline $\mathrm{R}^{2}$ & & $0.34^{*}$ & $0.41^{*}$ & - & - & $0.58^{*}$ & $0.62^{*}$ & $0.44^{*}$ \\
\hline RMSE (\%) & & 85 & 91 & - & - & 85 & 68 & 87 \\
\hline RE (\%) & & 34 & 1 & - & - & 50 & 24 & 7 \\
\hline MD (\%) & & $6^{*}$ & 0 & - & - & $5^{*}$ & $2^{*}$ & $1^{*}$ \\
\hline \multicolumn{9}{|l|}{ Total $\mathrm{CO}_{2}$ fluxes $\mathrm{kg} \cdot \mathrm{C} \cdot \mathrm{ha}^{-1}$} \\
\hline Annual total $\mathrm{R}_{\text {eco }}$ & 6771 & 4455 & 6736 & - & - & - & - & - \\
\hline Annual total $\mathrm{R}_{\mathrm{H}}$ & & & & & - & 1826 & 2668 & 3218 \\
\hline $\begin{array}{l}\text { Annual total } \mathrm{R}_{\mathrm{H}} \\
\text { (4 yrs average) }\end{array}$ & & & & & 3624 & 1794 & 2744 & 3387 \\
\hline
\end{tabular}

"Significant at 5\% level of probability. ! = estimated using DailyDayCent derived ratio; $\phi=\mathrm{R}_{\text {eco }}$ estimated using a conversion ratio derived from DNDC outputs for ECOSSE and DailyDayCent. $\mathrm{R}^{2}=$ Coefficient of determination; RMSE = Root Mean Square Error; RE = Relative Error (Mean); $\mathrm{MD}=$ Mean Difference. 

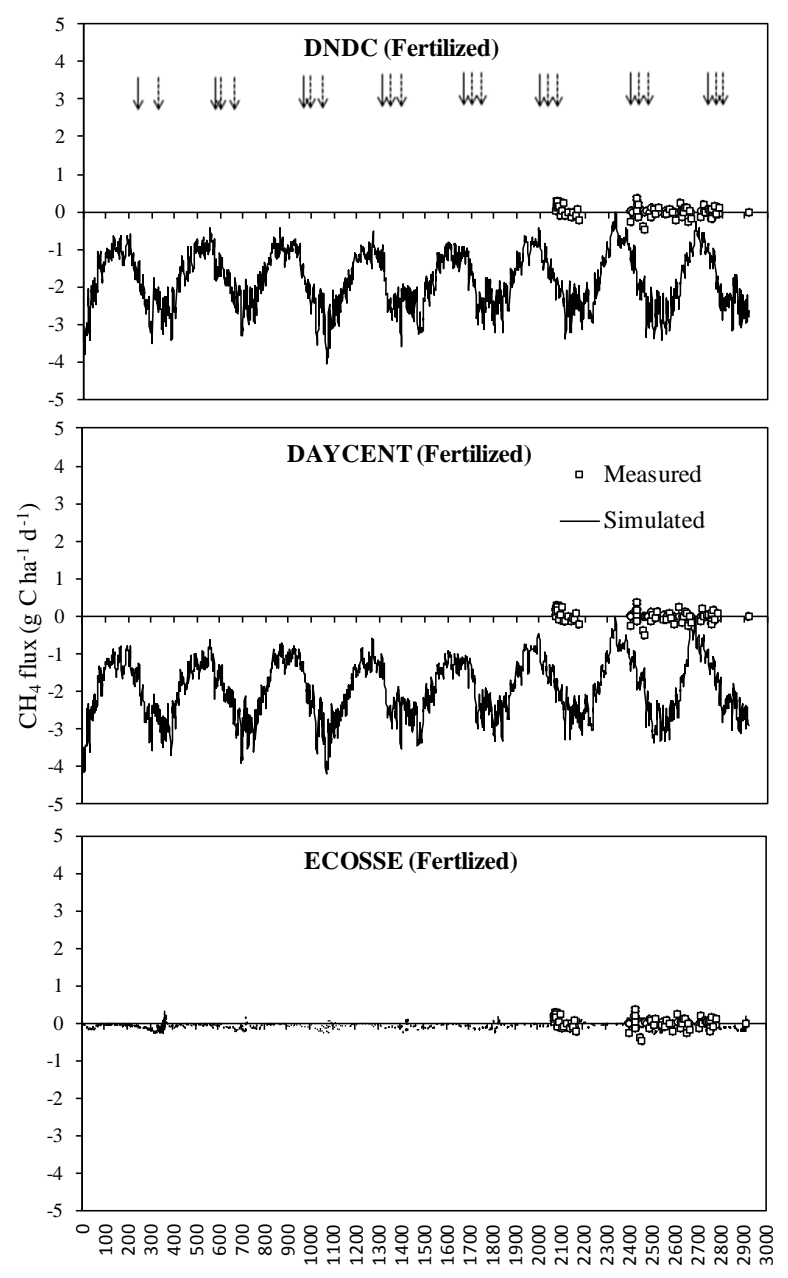

Days after harvest of previous crop (2003)
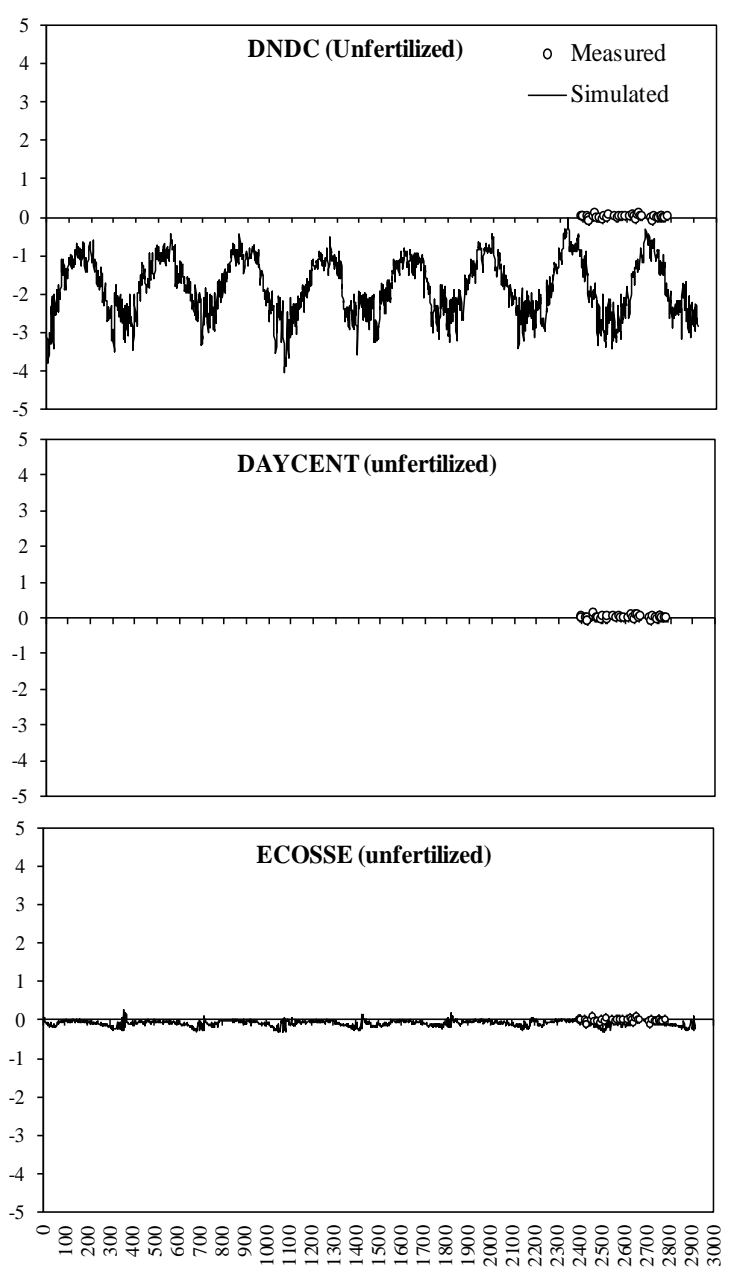

Days after harvest of previous crop (2003)

Figure 4. Comparison of field measured (seasonal/annual; open circle/square with vertical bars as standard errors) $\mathrm{CH}_{4}$ emissions/oxidation ( $\mathrm{g} \cdot \mathrm{N} \cdot \mathrm{ha}^{-1}$ ) with values simulated (line) using the three process-based models over 8 years, commencing from 17 August 2003 (day of harvest), in conventionally-tilled fertilized arable land cropped to spring barley. Solid arrows indicate the days of ploughing and dotted arrows indicate the days of $\mathrm{N}$ fertilizer application.

large bias and error differences between them (Table 5). The ECOSSE simulated values correlated well $\left(\mathrm{R}^{2}=\right.$ $0.34, p<0.05$ ), with the total bias and error differences between simulated and measured values were at $<95 \%$ confidence intervals. For the unfertilized plots, either model estimates showed low $\mathrm{R}^{2}$ values, large total biases and errors.

Annual budgets based on the measured data showed the arable land to be a small $\mathrm{CH}_{4}$ source, with an emission of $2.35 \mathrm{~g} \cdot \mathrm{C} \cdot \mathrm{ha}^{-1}$ from the unfertilized plot, increasing to $3.50 \mathrm{~g} \cdot \mathrm{C} \cdot \mathrm{ha}^{-1}$ for the fertilized plot (Table 5). For an 8-year average, the model estimates indicated that cropland was a sink for $\mathrm{CH}_{4}$, with the annual oxidation of $666 \mathrm{~g} \cdot \mathrm{C} \cdot \mathrm{ha}^{-1}$ predicted by DNDC, $704 \mathrm{~g} \cdot \mathrm{C} \cdot \mathrm{ha}^{-1}$ from the DailyDayCent and $28 \mathrm{~g} \cdot \mathrm{C} \cdot \mathrm{ha}^{-1}$ from the ECOSSE models. The integrated and sum of the daily flux approaches taken to calculate total $\mathrm{CH}_{4}$ fluxes showed a small difference.

\section{Discussion}

\subsection{Performance of the Models in Simulating Nitrate-N Concentrations}

Compared to the unfertilized field, the measured soil $\mathrm{NO}_{3}^{-}$concentration in the fertilized plot following CAN fertilizer application was higher. The decrease in soil $\mathrm{NO}_{3}^{-}$concentration over time is pre-assumed to have been due to plant uptake and other $\mathrm{N}$ loss processes, such as leaching. The DailyDayCent and DNDC-predicted 
Table 5. Validation of daily $\mathrm{CH}_{4}$ effluxes $\left(\mathrm{g} \cdot \mathrm{C} \cdot \mathrm{ha} \mathrm{a}^{-1} \cdot \mathrm{d}^{-1}\right)$ simulated by three process-based models with values measured from spring barley fields and their total fluxes.

\begin{tabular}{|c|c|c|c|c|c|c|c|c|}
\hline \multirow{2}{*}{ Statistical parameters } & \multicolumn{4}{|c|}{ Fertilized } & \multicolumn{4}{|c|}{ Unfertilized (Control) } \\
\hline & DNDC & & DailyDayCent & ECOSSE & DNDC & & DailyDayCent & ECOSSE \\
\hline $\mathrm{R}^{2}$ & 0.02 & & 0.02 & 0.34 & 0.02 & & - & 0.07 \\
\hline RMSE (\%) & $18,926^{*}$ & & $183,761^{*}$ & 401 & $38,037^{*}$ & & - & $2286^{*}$ \\
\hline RMSE $_{95 \%}(\%)$ & 14,821 & & 14,821 & 14,821 & 2071 & & - & 2071 \\
\hline $\mathrm{RE}(\%)$ & $17,564^{*}$ & & $16,786^{*}$ & -65 & $35,238^{*}$ & & - & $1670^{*}$ \\
\hline $\mathrm{RE}_{95 \%}(\%)$ & 101,499 & & 101,499 & 101,499 & 1318 & & - & 1318 \\
\hline MD (\%) & $2^{*}$ & & $2^{*}$ & $4^{*}$ & $2^{*}$ & & - & $0^{*}$ \\
\hline Total annual fluxes $\left(\mathrm{g} \cdot \mathrm{C} \cdot \mathrm{ha}^{-1}\right)$ & Measured & DNDC & DailyDayCent & ECOSSE & Measured & DNDC & DailyDayCent & ECOSSE \\
\hline Integrated & 3.50 & -646 & -612 & -25 & 2.35 & -729 & - & -31.1 \\
\hline Sum of daily flux & & -682 & -657 & -28 & & -712 & - & -31.4 \\
\hline 8 years average & & -666 & -704 & -28 & & -667 & - & -30.3 \\
\hline
\end{tabular}

*Significant at 5\% level of probability. $\mathrm{R}^{2}$ = Coefficient of determination; RMSE = Root Mean Square Error; RE = Relative Error (Mean); MD = Mean Difference.

soil $\mathrm{NO}_{3}^{-}$levels are noisy, and attributed to a mismatch between plant $\mathrm{N}$ uptake and other $\mathrm{N}$ loss processes, or due to errors associated with the crop growth module, particularly for the latter model. Moreover, the simulated upper or lower limit of $\mathrm{NO}_{3}^{-}$levels are generally above the measurement values. Similar large overestimations were reported by others [24] [25] [38] [45] using the earlier DNDC versions. This may be ascribed to limitations in the ability of the models to accurately account for variable soil depth increments or movement through soils and/or high mineralization of $\mathrm{N}$ and rapid nitrification.

The ECOSSE simulated values are closer to the amount of $\mathrm{NO}_{3}-\mathrm{N}$ applied, in line with the results of other researchers [36], and consistent over the 8 years, unlike the simulations predicted by the other two. With the exception of fertilizer-induced peaks in $\mathrm{NO}_{3}^{-}$, there were small differences between fertilized and unfertilized plots. Statistical evaluations confirm that the ECOSSE model can simulate soil $\mathrm{NO}_{3}^{-}$well $\left(\mathrm{R}^{2}=0.50\right)$ for the fertilized field, and that it performs better than DNDC $\left(\mathrm{R}^{2}=0.31\right)$ and DailyDayCent $\left(\mathrm{R}^{2}=0.14\right)$. However, all the models have difficulties in predicting background levels of soil $\mathrm{NO}_{3}^{-}$, though the total bias and error differences are within their 95\% confidence intervals, in line with the DNDC v9.2 estimates [25].

\subsection{Simulation Capacity of the Models for GHG Emissions}

\subsection{1. $\mathrm{N}_{2} \mathrm{O}$ Emissions}

Simulated $\mathrm{N}_{2} \mathrm{O}$ emissions using the three models are reasonably consistent over the different years. However, all models are unable to predict $\mathrm{N}_{2} \mathrm{O}$ fluxes less than zero. This contrasts with the measured values where a sink of $\mathrm{N}_{2} \mathrm{O}$ under conditions of low oxygen and/or mineral $\mathrm{N}$ was observed [7] [46]. DailyDayCent simulated $\mathrm{N}_{2} \mathrm{O}$ fluxes reasonably well. The total bias and error differences are somewhat large but within their 95\% confidence levels. This indicates a high predictive potentials for the models although only the ECOSSE-simulated values show a significant relationship with the measured ones under fertilized conditions, in agreement with other observations [36] [38]. Higher $\mathrm{R}^{2}$ values for cumulative $\mathrm{N}_{2} \mathrm{O}$ fluxes derived from DNDC simulated values were reported by other workers [25] but these did not correspond with the daily fluxes. Similar strong relationships for total $\mathrm{N}_{2} \mathrm{O}$ fluxes might be achieved from the other two models; however, the overall performance mainly depends on daily fluxes. Given that the simulated values were within the $95 \%$ confidence intervals, none of the models simulated daily $\mathrm{N}_{2} \mathrm{O}$ fluxes particularly well for the unfertilized field. Thus, an appropriate methodological compromise for the calculation of EFs may not be achievable without considering other factors controlling $\mathrm{N}_{2} \mathrm{O}$ emissions.

For the fertilized fields, both DNDC and DailyDayCent underestimated, and the ECOSSE model overestimated the total $\mathrm{N}_{2} \mathrm{O}$ fluxes (seasonal/annual). Based on an 8-year average, DNDC simulated total fluxes are 2 15 times lower than the DailyDayCent and the ECOSSE estimates. The variations among the model estimates 
and their relationship with key driving forces such as soil water and $\mathrm{NO}_{3}^{-}$levels are assumed to be functionally related to the production and release of $\mathrm{N}_{2} \mathrm{O}$ [28]. These are consistent with the DNDC and the DailyDayCent-simulated peaks. This indicates that both models consider denitrification as the major contributor to $\mathrm{N}_{2} \mathrm{O}$ production. In contrast, nitrification might be the major pathway in the ECOSSE model and the $\mathrm{N}_{2} \mathrm{O}$ fluxes are reasonably consistent with the simulated $\mathrm{NO}_{3}^{-}$levels; however, further enhancement of the emissions is possible with increasing soil water contents provided that substrate supply is not limiting [37]. The results from ECOSSE are in general agreement with the literature values for total $\mathrm{N}_{2} \mathrm{O}$ emissions from crop fields, which range from 0.7 to $3.5 \mathrm{~kg} \cdot \mathrm{N} \cdot \mathrm{ha}^{-1} \cdot \mathrm{yr}^{-1}$ [47]-[50]. The inconsistencies and uncertainties in the modelled predictions are thought to be partially associated with differences in model version, methods of data analyses, and crop managements between years as well as the use of default values particularly for DNDC and DailyDayCent.

Similarly, a large underestimations of $\mathrm{N}_{2} \mathrm{O}$ EFs by DNDC as well as by DailyDayCent, compared to the measured data, are evident. Estimation of EFs using simulated values is constrained by total flux differences between the fertilized and unfertilized plots. Replacement of unfertilized values by using background annual $\mathrm{N}_{2} \mathrm{O}$ emissions of $1 \mathrm{~kg} \cdot \mathrm{N} \cdot \mathrm{ha}^{-1}$ [41] could also be erroneous. Similar overall underestimations, particularly using the earlier versions of DNDC, have been reported [24] [25] [51]. This may be attributed to the limited number of field measurements, as this could result in large uncertainties in the measured values [52]. The fact that the DailyDayCent model also underestimated the $\mathrm{N}_{2} \mathrm{O}$ EF (44\%), with similar findings using DayCent ( 25\%), when compared with the default annual value, was reported by Del Grosso et al. (2005). In contrast, the ECOSSE model, on average, increased the EF by $35 \%$, but was within a closer range of the measured estimate $(0.52 \%)$. This is in line with the previous version of the model used [53], although it is still lower than the IPCC default value (1\%).

There is a discrepancy between the integration approach and the corresponding sum of daily fluxes in calculating the total/cumulative $\mathrm{N}_{2} \mathrm{O}$ fluxes, which may under or overestimate the values, depending on the corresponding peak sizes, and thereby influence the EFs. Nitrous oxide emissions show large temporal and/or spatial variability [54], resulting in an EF uncertainty of $>50 \%$ [55] [56]. This uncertainty could be more significant over several years of measurements than management-induced variations [49] [57]. However, the lower measured total $\mathrm{N}_{2} \mathrm{O}$ fluxes and the corresponding EFs may be explained by the application of CAN during a relatively dry period, leading to less denitrification, and a higher SOC density, which is favourable for complete denitrification to occur under anoxic conditions. The above statement remains equivocal due to intermittent gas sampling, suggesting the need for intensive/continuous sampling to cover the impact of tillage, fertilization, rainfall events and other environmental factors that regulate the degree of $\mathrm{N}_{2} \mathrm{O}$ emissions. Moreover, further improvements of the models by identifying errors associated with the processes that interactively produce $\mathrm{N}_{2} \mathrm{O}$ are imperative. The use of more robust measurement protocols are also required for accurate validation and calculation of $\mathrm{N}_{2} \mathrm{O}$ EFs across disaggregated land use types and in response to different management practices.

\subsubsection{Ecosystem and Heterotrophic Respiration}

The simulated values for $\mathrm{R}_{\text {eco }}$ from both DailyDayCent and DNDC demonstrated good correlation with the measured values $\left(\mathrm{R}^{2}=0.41\right.$ versus $\left.0.34, p<0.05\right)$, with relatively small total bias and error differences. Likewise, DNDC simulates well the cumulative $\mathrm{CO}_{2}$ fluxes of cropland sites in Europe, except for some overestimation of net $\mathrm{CO}_{2}$ uptake [58]. It was found that DayCent provided robust simulated $\mathrm{CO}_{2}$ emissions for various land use systems [18]. Our study indicates that a further improvement of both models is required to remove the discrepancy with regard to the mis-match between the simulated $\mathrm{CO}_{2}$ peaks and the measured values. Irrespective of the models, this shift cannot be seen for $R_{H}$ in the modelled values, which correlated well $\left(R^{2}=0.44\right.$ $0.62 ; p<0.05$ ), with small biases and errors. The DailyDayCent and DNDC simulated $\mathrm{R}_{\mathrm{H}}$ better than ECOSSE. The relatively poor performance of ECOSSE is probably due to the estimation errors associated with the requirement to convert the measured $\mathrm{R}_{\text {eco }}$ data to $\mathrm{R}_{\mathrm{H}}$.

Accordingly, the annual estimates for the total $\mathrm{R}_{\text {eco }}$ measured using EC $\left(6771 \mathrm{~kg} \cdot \mathrm{C} \cdot \mathrm{ha} \mathrm{a}^{-1}\right)$ is closer to the global cropland average $\left(5440 \pm 800 \mathrm{~kg} \cdot \mathrm{C} \cdot \mathrm{ha}^{-1}\right)$ [59]. The measured value is similar to the DailyDayCent predictions whilst DNDC underestimated it by 34\%, which may be attributed to the poor prediction of soil water content between $50 \%$ and $80 \%$ WFPS [60] [61] or around 55\% - 60\% [62]. Soil water as a confounding factor together with soil temperature also regulates the processes involved in decomposition [63]. Decomposition decreases as the soil dries the extent of the decrease is determined by diffusion limitations and the availability of oxygen [64]. Higher temperatures are often accompanied by low water contents and vice versa [65] and the strong interdependencies between these two factors make it difficult to separate their effects on soil respiration. Moreover, it 
was reported that DNDC may not predict $\mathrm{R}_{\text {eco }}$ perfectly, due to some limitations in the crop growth module [66]. The crop growth module has an application of a sigmoid curve based upon degree days which require additional parameters, e.g. base temperature, degree days of phenology stages and radiation use efficiency to correctly define the growth curves for crops in terms of temporal carbon take up. Despite having a lower $\mathrm{R}^{2}$, the ECOSSE model simulated total $\mathrm{R}_{\mathrm{H}}$ values that were closer to the measured values, whilst the DailyDayCent and DNDC values underestimated it. Similar values based on the 8-year average were also observed, implying that the ECOSSE predicts $\mathrm{R}_{\mathrm{H}}$ better than the other two models. This can be attributed to the absence of crop growth and biomass-related inputs to run the models.

\subsection{3. $\mathrm{CH}_{4}$ Emission/Oxidation}

The measured data demonstrated both $\mathrm{CH}_{4}$ emissions and oxidation though the magnitude of the fluxes was relatively small. This might be linked to the contribution of $\mathrm{R}_{\mathrm{H}}$ with simultaneous influence of mainly soil water contents/precipitation events creating aerobic and anaerobic conditions [8]. The measured peaks for $\mathrm{CH}_{4} \mathrm{show}$ stimulating effect of $\mathrm{N}$ fertilization on both emissions and oxidation. The three models are unable to predict similar trends, and are assumed to be constrained by several regulating factors, so that consideration of the flux variations between fertilized and unfertilized fields may not be appropriate for judging the model's performance. Both DNDC and DailyDayCent predict $\mathrm{CH}_{4}$ oxidation, in line with former versions [38] [67], and the ECOSSE also provided values closer to the measured ones, showing small sources, particularly for the fertilized field. The simulated and measured values are poorly correlated, including remarkably high total bias and error differences, particularly with the DNDC and DailyDayCent models. The modified version of ECOSSE used in this study performs better $\left(\mathrm{R}^{2}=0.34\right)$ than the previous one [53]. Although the $\mathrm{CH}_{4}$ fluxes from arable lands might have less impact in terms of overall GHG accounting the functional relationship between $\mathrm{C}$ and $\mathrm{N}$ emissions need to be improved for accurate estimations.

The measured data show that cropland is a $\mathrm{CH}_{4}$ source that increases with the application of $\mathrm{N}$ fertilizer, indicating fertilizer-induced limitation for $\mathrm{CH}_{4}$ oxidation to occur. Arable soils are mainly considered as a sink rather than a source of $\mathrm{CH}_{4}$ [8] [68]. Indeed, tillage and $\mathrm{N}$ fertilization have a tendency to reduce oxidation potentials [69]. Increased $\mathrm{CH}_{4}$ oxidation in arable soils [46] may be linked to well aerated conditions with a positive redox potential that limits methanogenic activities through draining, coupled with ploughing [70]. The three models also demonstrated an annual reduction in $\mathrm{CH}_{4}$ oxidation from the $\mathrm{N}$ fertilizer-treated plots compared to the unfertilized ones. However, the higher predicted oxidation with the DNDC and DailyDayCent models compared to ECOSSE indicates that annual estimates are not in agreement with the amounts of mineral $\mathrm{N}$ either mineralized and/or applied as fertilizer. These results suggest that functional constraints on the DailyDayCent and DNDC models for predicting $\mathrm{CH}_{4}$ emissions were greater, in comparison to the ECOSSE model and assumed to be mainly due to input parametric limitations.

\section{Conclusion}

Compared to the measured values, ECOSSE could simulate nitrate concentration more robustly than DNDC and DailyDayCent. Both DNDC and DailyDayCent underestimated daily and total $\mathrm{N}_{2} \mathrm{O}$ fluxes compared to ECOSSE, providing an improved prediction of fertilizer-induced $\mathrm{N}_{2} \mathrm{O}$ fluxes and EFs. All models could simulate soil and/or heterotrophic respiration adequately, except for an underestimation with DNDC that may be related to the greater impact of variations in soil properties compared to other model predictions. Only the ECOSSE model was able to predict field $\mathrm{CH}_{4}$ emissions/oxidation that were closer to the measured ones, and demonstrate the overall dominance of oxidation processes. There are constraints in terms of processes and driving forces in all the models for predicting coupled $\mathrm{C}$ and $\mathrm{N}$ emissions, leading to the underestimation of GHGs. Thus, refinement and further validation of the models using country-specific activity data are required to better predict GHG emissions. In addition, to avoid a dependency on default inputs that may lead to significant errors in the model outputs more measurements are required that account for temporal and spatial variability. Furthermore, validations and sensitivity tests need to focus more on site-related characteristics, land use differences, management interventions, and climatic factors for providing national GHG estimates and for identification of mitigation options.

\section{Acknowledgements}

The senior author gratefully acknowledges the funding by the Science, Technology, Research and Innovation for 
the Environment (STRIVE) Programme of the Irish Government under the National Development Plan 2007-2013 and the Department of the Environment, Heritage and Local Government. The authors would like to thanks Phillip O'Brien (EPA) for extending technical and relevant support; Mike Williams, Mike Jones and Matt Saunders (TCD), Komsan Rueangritsarakul and Mohamed Helmy (UCD) for supplying experimental data for modelling work; as well as Tom Bolger and Tommy Gallagher (UCD) for providing administrative support.

\section{References}

[1] IPCC (2007) Climate Change 2007: The Physical Science Basis. In: Solomon, S., Qin, D., Manning, M., Chen, Z., Marquis, M., Averyt, K.B., Tignor, M. and Miller, H.L., Eds., Contribution of Working Group I to the Fourth Assessment Report of the Intergovernmental Panel on Climate Change, Cambridge University Press, Cambridge, 996 p.

[2] Weiske, A. and Petersen, S.O. (2006) Mitigation of Greenhouse Gas Emissions from Livestock Production. Agriculture, Ecosystems and Environment, 112, 105-106. http://dx.doi.org/10.1016/j.agee.2005.08.009

[3] Duffy, P., Hanley, E., Black, K., O’Brien, P., Hyde, B., Ponzi, J. and Alam, S. (2015) Ireland’s National Inventory Report 2015. Greenhouse Gas Emissions 1990-2013 Reported to the United Nations Framework Convention on Climate Change. Environmental Protection Agency (An Ghníomhaireacht um Chaomhnú Comhshaoil), Wexford, Ireland, $609 \mathrm{p}$.

[4] Conrad, R. (1996) Soil Microorganisms as Controllers of Atmospheric Trace Gases $\left(\mathrm{H}_{2}, \mathrm{CO}, \mathrm{CH}_{4}, \mathrm{OCS}, \mathrm{N}_{2} \mathrm{O}\right.$, and NO). Microbiology Review, 60, 609-640.

[5] Drury, C.F., Oloya, T.O., McKenney, D.J., Gregorich, E.G., Tan, C.S. and van Luyk, C.L. (1998) Long-Term Effects of Fertilization and Rotation on Denitrification and Soil Carbon. Soil Science Society of America Journal, 62, 15721579. http://dx.doi.org/10.2136/sssaj1998.03615995006200060014x

[6] Chan, A.S.K. and Parkin, T.B. (2001) Effect of Land Use on Methane Flux from Soil. Journal of Environmental Quality, 30, 786-797. http://dx.doi.org/10.2134/jeq2001.303786x

[7] Khalil, M.I., Rosenani, A.B., Van Cleemput, O., Fauziah, C.I. and Shamshuddin, J. (2002) Nitrous Oxide Emission from an Ultisol of the Humid Tropics under Maize-Groundnut Rotation. Journal of Environmental Quality, 31, 10711078. http://dx.doi.org/10.2134/jeq2002.1071

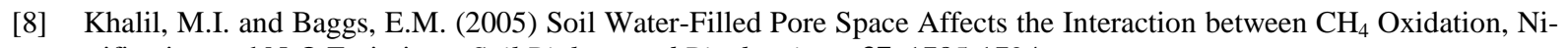
trification and $\mathrm{N}_{2} \mathrm{O}$ Emissions. Soil Biology and Biochemistry, 37, 1785-1794. http://dx.doi.org/10.1016/j.soilbio.2005.02.012

[9] Stehfest, E. and Bouwman, L. (2006) $\mathrm{N}_{2} \mathrm{O}$ and NO Emission from Agricultural Fields and Soils under Natural Vegetation: Summarizing Available Measurement Data and Modeling of Global Annual Emissions. Nutrient Cycling in Agroecosystems, 74, 207-228. http://dx.doi.org/10.1007/s10705-006-9000-7

[10] Rochette, P., Angers, D.A., Chantigny, M.H., Gagnon, B. and Bertrand, N. (2008) $\mathrm{N}_{2} \mathrm{O}$ Fluxes in Soils of Contrasting Textures Fertilized with Liquid and Solid Dairy Cattle Manures. Canadian Journal of Soil Science, 88, 175-187. http://dx.doi.org/10.4141/CJSS06016

[11] Richter, J. and Roelcke, M. (2000) The N-Cycle as Determined by Intensive Agriculture: Examples from Central Europe and China. Nutrient Cycling in Agroecosystems, 57, 33-46. http://dx.doi.org/10.1023/A:1009802225307

[12] Khalil, M.I. and Inubushi, K. (2007) Possibilities to Reduce Rice Straw-Induced Global Warming Potential of a Sandy Paddy Soil by Combining Hydrological Manipulations and Urea-N Fertilizations. Soil Biology and Biochemistry, 39, 2675-2681. http://dx.doi.org/10.1016/j.soilbio.2007.05.003

[13] Oenema, O., Bannink, A., Sommer, S.G. and Velthof, G.L. (2001) Gaseous Nitrogen Emissions form Livestock Farming Systems. In: Follett, R.F., Hatfield, J.L., Eds., Nitrogen in the Environment: Sources, Problems, and Management Ch. 10, Elsevier, Amsterdam, 255-289. http://dx.doi.org/10.1016/B978-044450486-9/50012-1

[14] IPCC (1996) Chapter 5, Land-Use Change and Forestry. Revised 1996 Guidelines for National Greenhouse Gas Inventories. In: Reference Manual, The Intergovernmental Panel on Climate Change, Blacknell, 5.6-5.75.

[15] IPCC (2006) Agriculture, Forestry and Other Land Use. In: Eggleston, H.S., Buendia, L., Miwa, K., Ngara, T., Tanabe K., Eds., IPCC Guidelines for National Greenhouse Gas Inventories, Institute for Global Environmental Strategies, Hayama, Prepared by the National Greenhouse Gas Inventories Programme.

[16] Giltrap, D.L., Li, C. and Saggar, S. (2010) DNDC: A Process-Based Model of Greenhouse Gas Fluxes from Agricultural Soils. Agriculture, Ecosystems and Environment, 136, 292-300. http://dx.doi.org/10.1016/j.agee.2009.06.014

[17] Ambus, P. and Christensen, S. (1995) Spatial and Seasonal Nitrous Oxide and Methane Fluxes in Danish Forest-, Grassland-, and Agroecosystems. Journal of Environmental Quality, 24, 993-1001. http://dx.doi.org/10.2134/jeq1995.00472425002400050031x

[18] Frolking, S.E., Mosier, A.R., Ojima, D.S., Li, C., Parton, W.J., Potter, C.S., et al. (1998) Comparison of $\mathrm{N}_{2} \mathrm{O}$ Emis- 
sions from Soils at Three Temperate Agricultural Sites: Simulations of Year-Round Measurements by Four Models. Nutrient Cycling in Agroecosystems, 52, 77-105. http://dx.doi.org/10.1023/A:1009780109748

[19] Li, C., Frolking, S. and Harriss, R. (1994) Modeling Carbon Biogeochemistry in Agricultural Soils. Global Biogeochemical Cycles, 8, 237-254. http://dx.doi.org/10.1029/94GB00767

[20] Parton, W.J., Hartman, M.D., Ojima, D.S. and Schimel, D.S. (1998) DAYCENT: Its Land Surface Submodel: Description and Testing. Global and Planetary Change, 19, 35-48. http://dx.doi.org/10.1016/S0921-8181(98)00040-X

[21] Del Grosso, S.J., Parton, W.J., Mosier, A.R., Hartman, M.D., Brenner, J., Ojima, D.S. and Schimel, D.S. (2001) Simulated Interaction of Carbon Dynamics and Nitrogen Trace Gas Fluxes Using the DAYCENT Model. In: Schaffer, M., Ma, L. and Hansen, S., Eds., Modeling Carbon and Nitrogen Dynamics for Soil Management, CRC Press, Boca Raton, 303-332.

[22] Smith, J.U., Gottschalk, P., Bellarby, P.J., Chapman, S., Lilly, A., Towers, W., et al. (2010) Estimating Changes in National Soil Carbon Stocks Using ECOSSE-A New Model That Includes Upland Organic Soils. Part I. Model Description and Uncertainty in National Scale Simulations of Scotland. Climate Research, 45, 179-192. http://dx.doi.org/10.3354/cr00899

[23] Gottschalk, P., Wattenbach, M., Neftel, A., Fuhrer, J., Jones, M., Lanigan, G., et al. (2007) The Role of Measurement Uncertainties for the Simulation of Grassland Net Ecosystem Exchange (NEE) in Europe. Agriculture, Ecosystems and Environment, 121, 175-185. http://dx.doi.org/10.1016/j.agee.2006.12.026

[24] Abdalla, M., Wattenbach, M., Smith, P., Ambus, P., Jones, M. and Williams, M. (2009) Application of the DNDC Model to Predict Emissions of $\mathrm{N}_{2} \mathrm{O}$ from Irish Agriculture. Geoderma, 151, 327-337. http://dx.doi.org/10.1016/j.geoderma.2009.04.021

[25] Abdalla, M., Rueangritsarakul, K., Jones, M., Osborne, B., Helmy, M., Roth, B., et al. (2012) How Effective Is Reduced Tillage-Cover Crop Management in Reducing $\mathrm{N}_{2} \mathrm{O}$ Fluxes from Arable Crop Soils? Water, Air and Soil Pollution, 223, 5155-5174. http://dx.doi.org/10.1007/s11270-012-1268-4

[26] Li, D., Lanigan, G. and Humphreys, J. (2011) Measured and Simulated $\mathrm{N}_{2} \mathrm{O}$ Emissions from Ryegrass and Ryegrass/ Clover Swards in a Moist Temperate Climate. PLoS ONE, 6, e26176. http://dx.doi.org/10.1371/journal.pone.0026176

[27] Rafique, R., Peichl, M., Hennessy, D. and Kiely, G. (2011) Evaluating Management Effects on Nitrous Oxide Emissions from Grasslands Using the Process-Based DeNitrification-DeComposition (DNDC) Model. Atmospheric Environment, 45, 6029-6039. http://dx.doi.org/10.1016/j.atmosenv.2011.07.046

[28] Xu, X., Liu, W., Zhang, C. and Kiely, G. (2011) Modeling the Change in Soil Organic Carbon of Grassland in Response to Climate Change: Effects of Measured versus Modeled Carbon Pools for Initializing the Rothamsted Carbon Model. Agriculture, Ecosystems and Environment, 140, 371-382. http://dx.doi.org/10.1016/j.agee.2010.12.018

[29] Byrne, K. and Kiely, G. (2012) Evaluation of Models (PaSim, RothC, CENTURY and DNDC) for Simulation of Grassland Carbon Cycling at Plot, Field and Regional Scale.

http://www.epa.ie/pubs/reports/research/land/STRIVE 20 Byrne GrassCarbonCycling web.pdf

[30] CSO (Central Statistics Office) (2016) Agriculture-Area Yield and Production of Selected Crops for 2014. http://www.cso.ie/quicktables/GetQuickTables.aspx?FileName=AQA04.asp\&TableName=Area+Yield+and+Productio n+of+Selected+Crops

[31] Khalil, M.I., Kiely, G., O’Brien, P. and Müller, C. (2013) Organic Carbon Stocks in Agricultural Soils in Ireland Using Combined Empirical and GIS Approaches. Geoderma, 193-194, 222-235. http://dx.doi.org/10.1016/j.geoderma.2012.10.005

[32] Abdalla, M., Jones, M., Ambus, P. and Williams, M. (2010) Emissions of $\mathrm{N}_{2} \mathrm{O}$ from Irish Arable Soils: Effects of Tillage and Reduced N Input. Nutrient Cycling in Agroecosystems, 86, 53-65. http://dx.doi.org/10.1007/s10705-009-9273-8

[33] Abdalla, M., Jones, M. and Williams. M. (2010) Simulation of $\mathrm{N}_{2} \mathrm{O}$ Fluxes from Irish Arable Soils: Effect of Climate Change and Management. Biology and Fertility of Soils, 46, 247-260. http://dx.doi.org/10.1007/s00374-009-0424-5

[34] Davis, P.A., Clifton Browne, J., Saunders, M., Lanigan, G., Wright, E., Fortune, T., et al. (2010) Assessing the Effects of Agricultural Management Practices on Carbon Fluxes: Spatial Variation and the Need for Replicated Estimates of Net Ecosystem Exchange. Agricultural and Forest Meteorology, 150, 564-574. http://dx.doi.org/10.1016/j.agrformet.2010.01.021

[35] Compton, J.E. and Boone, R.D. (2000) Long-Term Impacts of Agriculture on Soil Carbon and Nitrogen in New England Forests. Ecological Society of America, 81, 2314-2330. http://dx.doi.org/10.1890/0012-9658(2000)081[2314:ltioao]2.0.co;2

[36] Bell, M.J., Jones, E., Smith, J., Smith, P., Yeluripati, J., Augustin, J., Juszczak, R., Olejnik, J. and Sommer, M. (2012) Simulation of Soil Nitrogen, Nitrous Oxide Emissions and Mitigation Scenarios at 3 European Cropland Sites Using the ECOSSE Model. Nutrient Cycling in Agroecosystems, 92, 161-181. http://dx.doi.org/10.1007/s10705-011-9479-4 
[37] Khalil, M.I., Richards, M., Osborne, B., Williams, M. and Müller, C. (2013) Simulation and Sensitivity of Greenhouse Gas Emissions and SOC Stock to Arable Site Characteristics and Management Using the ECOSSE Model. Atmospheric Environment, 81, 616-624. http://dx.doi.org/10.1016/j.atmosenv.2013.09.038

[38] Smith, P., Martino, D., Cai, Z., Gwary, D., Janzen, H., Kumar, P., et al. (2007) Agriculture. In: Metz, B., Davidson, O.R., Bosch, P.R., Dave, R. and Meyer, L.A., Eds., Climate Change 2007: Mitigation. Contribution of Working Group III to the 4th Assessment Report of the Intergovernmental Panel on Climate Change, Cambridge University Press, Cambridge, 497-540.

[39] Li, C.S. (2000) Modeling Trace Gas Emissions from Agricultural Ecosystems. Nutrient Cycling in Agroecosystems, 58, 259-276. http://dx.doi.org/10.1023/A:1009859006242

[40] Li, C.S. (2007) Quantifying Greenhouse Gas Emissions from Soils: Scientific Basis and Modeling Approach. Soil Science and Plant Nutrition, 53, 344-352. http://dx.doi.org/10.1111/j.1747-0765.2007.00133.x

[41] Parton, W.J., Mosier, A.R., Ojima, D.S., Valentine, D.W., Schimel, D.S., Weier, K. and Kulmala, A.E. (1996) Generalized Model for $\mathrm{N}_{2}$ and $\mathrm{N}_{2} \mathrm{O}$ Production from Nitrification and Denitrification. Global Biogeochemical Cycles, 10, 401-412. http://dx.doi.org/10.1029/96GB01455

[42] Del Grosso, S.J., Ojima, D.S., Parton, W.J., Mosier, A.R., Petereson, G.A. and Schimel, D.S. (2002) Simulated Effects of Dryland Cropping Intensification on Soil Organic Matter and Greenhouse Gas Exchanges Using the DAYCENT Ecosystem Model. Environmental Pollution, 116, S75-S83. http://dx.doi.org/10.1016/s0269-7491(01)00260-3

[43] Del Grosso, S.J., Parton, W.J., Adler, P.R., Davis, S., Keogh, C. and Marx, E. (2012) DayCent Model Simulations for Estimating Soil Carbon Dynamics and Greenhouse Gas Fluxes from Agricultural Production Systems. Book Chapter, Elsevier Inc., New York, 241-250. http://dx.doi.org/10.1016/b978-0-12-386897-8.00014-0

[44] Smith, J.U. and Smith, P. (2010) A Worksheet to Compare Modelled with Measured Results (MODEVAL v2.0). School of Biological Sciences, University of Aberdeen, Aberdeen.

[45] Del Grosso, S.J., Mosier, A.R., Parton, W.J. and Ojima, D.S. (2005) DAYCENT Model Analysis of Past and Contemporary Soil $\mathrm{N}_{2} \mathrm{O}$ and Net Greenhouse Gas Flux for Major Crops in the USA. Soil and Tillage Research, 83, 9-24. http://dx.doi.org/10.1016/j.still.2005.02.007

[46] Chapuis-Lardy, L., Wrange, N., Metay, A., Chotte J.L. and Bernoux, M. (2007) Soils, a Sink for $\mathrm{N}_{2} \mathrm{O}$ ? A Review. Global Change Biology, 13, 1-17. http://dx.doi.org/10.1111/j.1365-2486.2006.01280.x

[47] Kaiser, E.A. and Heinemeyer, O. (1996) Temporal Changes in $\mathrm{N}_{2} \mathrm{O}$-Losses from Two Arable Soils. Plant and Soil, 181, 57-63. http://dx.doi.org/10.1007/BF00011292

[48] Flessa, H., Wild, U., Klemisch, M. and Pfadenhauer, J. (1998) Nitrous Oxide and Methane Fluxes from Organic Soils under Agriculture. European Journal of Soil Science, 49, 327-335. http://dx.doi.org/10.1046/j.1365-2389.1998.00156.x

[49] Kaiser, E.A., Kohrs, K., Kucke, M., Schnug, E., Heinemeyer, O. and Munch, J.C. (1998) Nitrous Oxide Release from Arable Soil: Importance of N Fertilization, Crops and Temporal Variation. Soil Biology and Biochemistry, 30, 15531563. http://dx.doi.org/10.1016/S0038-0717(98)00036-4

[50] De Gryze, S., Wolf, A., Kaffka, S.R., Mitchell, J., Rolston, D.E., Temple, S.R., Lee, J. and Six, J. (2010) Simulating Greenhouse Gas Budgets of Four California Cropping Systems under Conventional and Alternative Management. Ecological Applications, 20, 1805-1819. http://dx.doi.org/10.1890/09-0772.1

[51] Beheydt, D., Boeckx, P., Sleutel, S., Li, C. and Van Cleemput, O. (2007) Validation of DNDC for 22 Long-Term $\mathrm{N}_{2} \mathrm{O}$ Field Emission Measurements. Atmospheric Environment, 41, 6196-6211. http://dx.doi.org/10.1016/j.atmosenv.2007.04.003

[52] Parkin, T.B. (2008) Effect of Sampling Frequency on Estimates of Cumulative Nitrous Oxide Emissions. Journal of Environmental Quality, 37, 1390-1395. http://dx.doi.org/10.2134/jeq2007.0333

[53] Khalil, M.I., Smith, J.U., Abdalla, M., O’Brien, P., Smith, P. and Müller, C. (2012) Simulation of Greenhouse Gases and Organic Carbon in an Irish Arable Land Using the ECOSSE Model. Proceedings of the Agricultural Research Forum Meeting, Tullamore, 12-13 March 2012, 110.

[54] Khalil, M.I., Van Cleemput, O., Rosenani, A.B. and Schmidhalter, U. (2007) Daytime, Temporal and Seasonal Variations of $\mathrm{N}_{2} \mathrm{O}$ Emissions in an Upland Cropping System of the Humid Tropics. Communications in Soil Science and Plant Analysis, 38, 189-204. http://dx.doi.org/10.1080/00103620601094122

[55] Lim, B., Boileau, P., Bonduki, Y., van Amstel, A.R., Janssen, L.H.J.M., Oliveier, J.G.J. and Kroeze, C. (1999) Improving the Quality of National Greenhouse Gas Inventories. Environmental Science and Policy, 2, 335-346. http://dx.doi.org/10.1016/S1462-9011(99)00023-4

[56] Mosier, A., Kroeze, C., Nevison, C., Oenema, O., Seitzinger, S. and van Cleemput, O. (1999) An Overview of the Revised 1996 IPCC Guidelines for National Greenhouse Gas Inventory Methodology for Nitrous Oxide from Agriculture. Environmental Science \& Policy, 2, 325-333. 
[57] Clayton, H., McTaggart, I.P., Parker, J., Swan, L. and Smith, K.A. (1997) Nitrous Oxide Emission from Fertilised Grassland: A 2-Year Study of the Effects of N Fertiliser Form and Environmental Conditions. Biology and Fertility of Soils, 25, 252-260. http://dx.doi.org/10.1007/s003740050311

[58] Dietiker, D., Buchmann, N. and Eugster, W. (2010) Testing the Ability of the DNDC Model to Predict $\mathrm{CO}_{2}$ and Water Vapour Fluxes of a Swiss Cropland Site. Agriculture, Ecosystems and Environment, 139, 396-401. http://dx.doi.org/10.1016/j.agee.2010.09.002

[59] Raich, J.W. and Schelesinger, W.H. (1992) The Global Carbon Dioxide Flux in Soil Respiration and Its Relationship to Vegetation and Climate. Tellus, 44B, 81-99. http://dx.doi.org/10.1034/j.1600-0889.1992.t01-1-00001.X

[60] Pal, D. and Broadbent, F.E. (1975) Influence of Moisture on Rice Straw Decomposition in Soils. Soil Science Society of America Journal, 39, 59-63. http://dx.doi.org/10.2136/sssaj1975.03615995003900010018x

[61] Weihermüller, L., Huisman, J.A., Graf, A., Herbst, M. and Sequaris, J.-M. (2009) Multistep Outflow Experiments for the Simultaneous Determination of Soil Physical and $\mathrm{CO}_{2}$ Production Parameters. Vadose Zone Journal, 8, 772-782. http://dx.doi.org/10.2136/vzj2008.0041

[62] Doran, J.W., Mielke, L.N. and Stamatiadis, S. (1988) Microbial Activity and N Cycling as Regulated by Soil WaterFilled Pore Space. In: Witney, B.D., Spoor, G., Soane, B.D. and Douglas, J.T., Eds., Tillage and Traffic in Crop Production: Proceedings of the 11th International Soil Tillage Research Organization, Vol. 1, International Soil Tillage Research Organization, Edinburgh, 49-54.

[63] Reichstein, M. and Beer, C. (2008) Soil Respiration across Scales: The Importance of a Model-Data Integration Framework for Data Interpretation. Journal of Plant Nutrition and Soil Science, 171, 344-354. http://dx.doi.org/10.1002/jpln.200700075

[64] Paustian, K., Andrén, O., Janzen, H.H., Lal, R., Smith, P., Tian, G., et al. (1997) Agricultural Soils as a Sink to Mitigate $\mathrm{CO}_{2}$ Emissions. Soil Use and Management, 13, 230-244. http://dx.doi.org/10.1111/j.1475-2743.1997.tb00594.x

[65] Davidson, E.A., Belk, E. and Boone, R.D. (1998) Soil Water Content and Temperature as Independent or Confounded Factors Controlling Soil Respiration in a Temperate Mixed Hardwood Forest. Global Change Biology, 4, $217-227$. http://dx.doi.org/10.1046/j.1365-2486.1998.00128.x

[66] Abdalla, M., Saunders, M., Hastings, A., Williams, M., Smith, P., Osborne, B., Lanigan, G. and Jones, M.B. (2013) Simulating the Impacts of Land Use in Northwest Europe on Net Ecosystem Exchange (NEE): The Role of Arable Ecosystems, Grasslands and Forest Plantations in Climate Change Mitigation. Science of the Total Environment, 465, 325-336. http://dx.doi.org/10.1016/j.scitotenv.2012.12.030

[67] Li, C.S., Frolking, S. and Butterbach-Bahl, K. (2005) Carbon Sequestration in Arable Soils Is Likely to Increase Nitrous Oxide Emissions, Offsetting Reductions in Climate Radiative Forcing. Climatic Change, 72, 321-338. http://dx.doi.org/10.1007/s10584-005-6791-5

[68] Bodelier, P.L.E. and Laanbroek, H.J. (2004) Nitrogen as a Regulatory Factor of Methane Oxidation in Soils and Sediments. FEMS Microbiology and Ecology, 47, 265-277. http://dx.doi.org/10.1016/S0168-6496(03)00304-0

[69] Bronson, K.F. and Mosier, A.R. (1993) Nitrous Oxide Emission and Methane Consumption in Wheat and Corn Cropped Systems in Northeastern Colorado. In: Harper, L.A., Mosier, A.R., Duxbury J.M. and Rolston, D.E., Eds., Agricultural Ecosystem Effects on Trace Gases and Global Climate Change, ASA Special Publication No. 55, ASA, CSSA and SSSA, Madison, 133-144.

[70] Borken, W., Xu, Y.-J. and Beese, F. (2003) Conversion of Hardwood Forests to Spruce and Pine Plantations Strongly Reduced Soil Methane Sink in Germany. Global Change Biology, 9, 956-966.

http://dx.doi.org/10.1046/j.1365-2486.2003.00631.x 


\section{Submit or recommend next manuscript to SCIRP and we will provide best service for you:}

Accepting pre-submission inquiries through Email, Facebook, LinkedIn, Twitter, etc.

A wide selection of journals (inclusive of 9 subjects, more than 200 journals)

Providing 24-hour high-quality service

User-friendly online submission system

Fair and swift peer-review system

Efficient typesetting and proofreading procedure

Display of the result of downloads and visits, as well as the number of cited articles

Maximum dissemination of your research work

Submit your manuscript at: http://papersubmission.scirp.org/ 